$\frac{\text { PNL-2598 }}{\text { UC-70 }}$

\title{
Summary of National and International Radioactive Waste Management Programs (Excluding United States)
}

by

K. M. Harmon

March 1978

Pacific Northwest Laboratory Richland, Washington 99352

Operated for the

U.S. Department of Energy

by 


\title{
NOTICE
}

This report was prepared 25 an account of work sponsored by the United States Government. Neither the United States nor the Department of Energy, nor any of their emplovees, nor any of their contractors. subcontuactors, or their employees, makes any warranty, express or implied, or assumes any legal liability or responsibility for the accuracy, completeness or usefulness of any information, apparatus, product or process disclosed, or represents that its use would nor infringe privately owned rights.

The views, opinions and conclusions contained in this report are those of the contractor and do not necessarily represent those of the United States Government or the United States Department of Energy.

1

\author{
PACIFIC NORTHWEST LABORATORY \\ operated by \\ BATTELLE \\ for the \\ UNITED STATES DEPARTMENT OF ENERGY \\ Lnder Contract EY-76-C-06-1330
}

\author{
Printed in the United States of America \\ Available from \\ National Technical Information Service \\ United States Department of Commerce \\ 5285 Port Royal Road \\ Springtield, Virginia 22151 \\ Price: Printed Copys_: Microtiche 53.00
}

\section{NTIS}

*Pages Selling Price

$\begin{array}{ll}001-025 & \$ 4.50\end{array}$

$026-050 \quad 55,00$

$\begin{array}{ll}05 i-075 & 55.50 \\ 076-100 & 55.00\end{array}$

$076-100 \quad 56.00$

$101-125=\$ 56.50$

$126-150 \quad 57.00$

$151 \cdot 175-5735$

$176-200 \quad 58.50$

$201-225 \quad+\quad 58.75$

$226-250 \quad 59.00$

$757-275 \quad 510.00$

$276-303=510.25$ 


\section{1}

$P N L-2598$

SUMMARY OF NATIONAL AND INTERNATIONAL RADIOACTIVE WASTE MANAGEMENT PROGRAMS (EXcluding United States)

by

K. M. Harmon, Manager

International Program Review

March 1978

BATTELLE

Pacific Northwest Laboratories

Richland, Washington 99352 


\section{CONTENTS}

GLOSSARY OF ACRONYMS AND ABBREVIATIONS

INTRODUCTION.

TABLE SUMMARIES

NUCLEAR FUEL CYCLE PROGRAMS IN SELECTED COUNTRIES . . . . . . . 4

URANIUM ENRICHMENT . . . . . . . . . . . . . . . . . . . 6

FUEL FABRICATION . . . . . . . . . . . . . . . . . 8

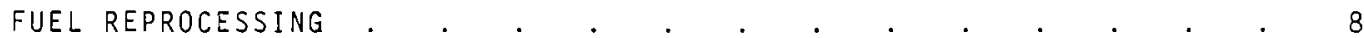

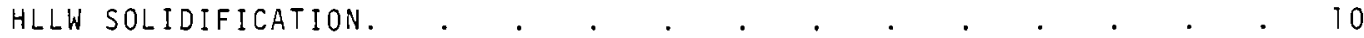

GEOLOGIC WASTE ISOLATION . . . . . . . . . . . . . . . . 12

NATIONAL AND INTERNATIONAL PROGRAM OVERVIEWS. . . . . . . . . . . . . 14

ARGENTINA • . . . . . . . . . . . . . . . 14

AUSTRALIA . . . . . . . . . . . . . . . . . . . . 14

AUSTRIA. . . . . . . . . . . . . . . . .

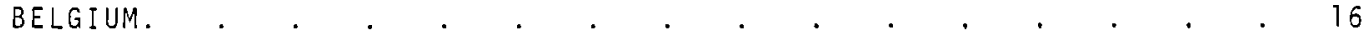

BRA Z I L

CANADA

FRANCE

GERMANY, FEDERAL REPUBLIC OF (FRG) . . . . . . . . . . . . . 22

INDIA . . . . . . . . . . 26

IRAN . . . . . . . . . . . , 27

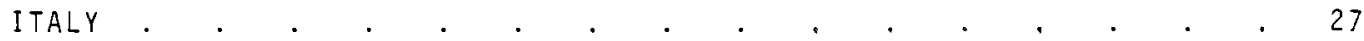

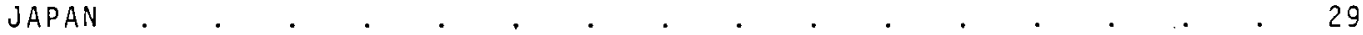

SPAIN $. \quad . \quad . \quad . \quad . \quad . \quad . \quad . \quad . \quad . \quad . \quad . \quad . \quad . \quad . \quad . \quad 30$

SWEDEN.

SWITZERLAND.

UNITED KINGDOM

USSR

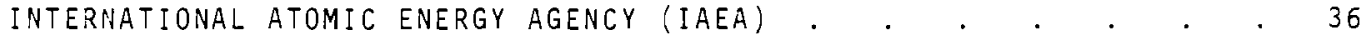

COMMISSION OF THE EUROPEAN COMMUNITIES (CEC) . . . . . . . . . 37

CEC: Joint Research Centre (Ispra) . . . . . . . . . . . 37

OECD NUCLEAR ENERGY AGENCY (NEA) . . . . . . . . . . . . . . . . 39

Eurochemic. . . . . . . . . . . . 39

COUNCIL FOR MUTUAL ECONOMIC ASSISTANCE (CMEA) . . . . . . . . 41

REFERENCES . . . . . . . . . . . . . . . . . . . . 42 


\section{FIGURES}

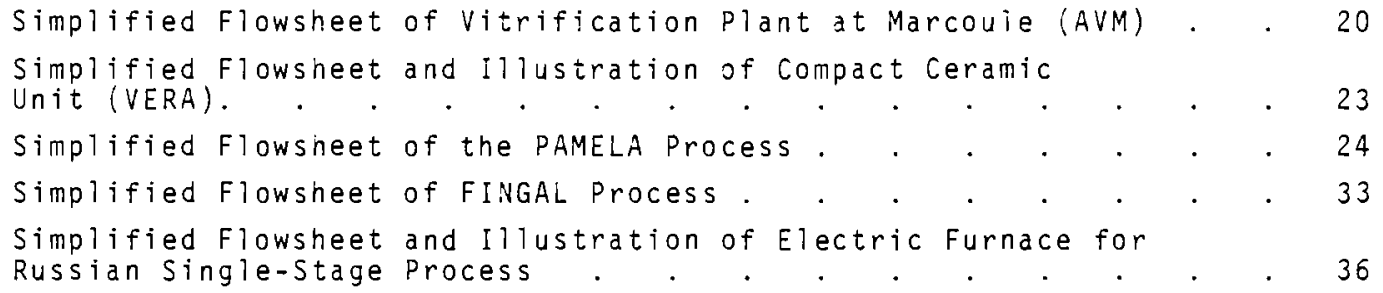

\section{TABLES}

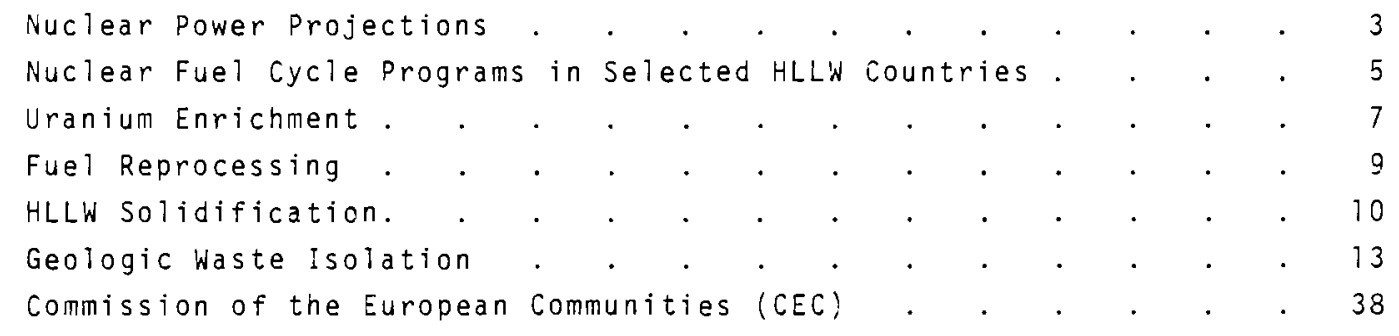




\section{ACRONYMS AND ABBREVIATIONS}

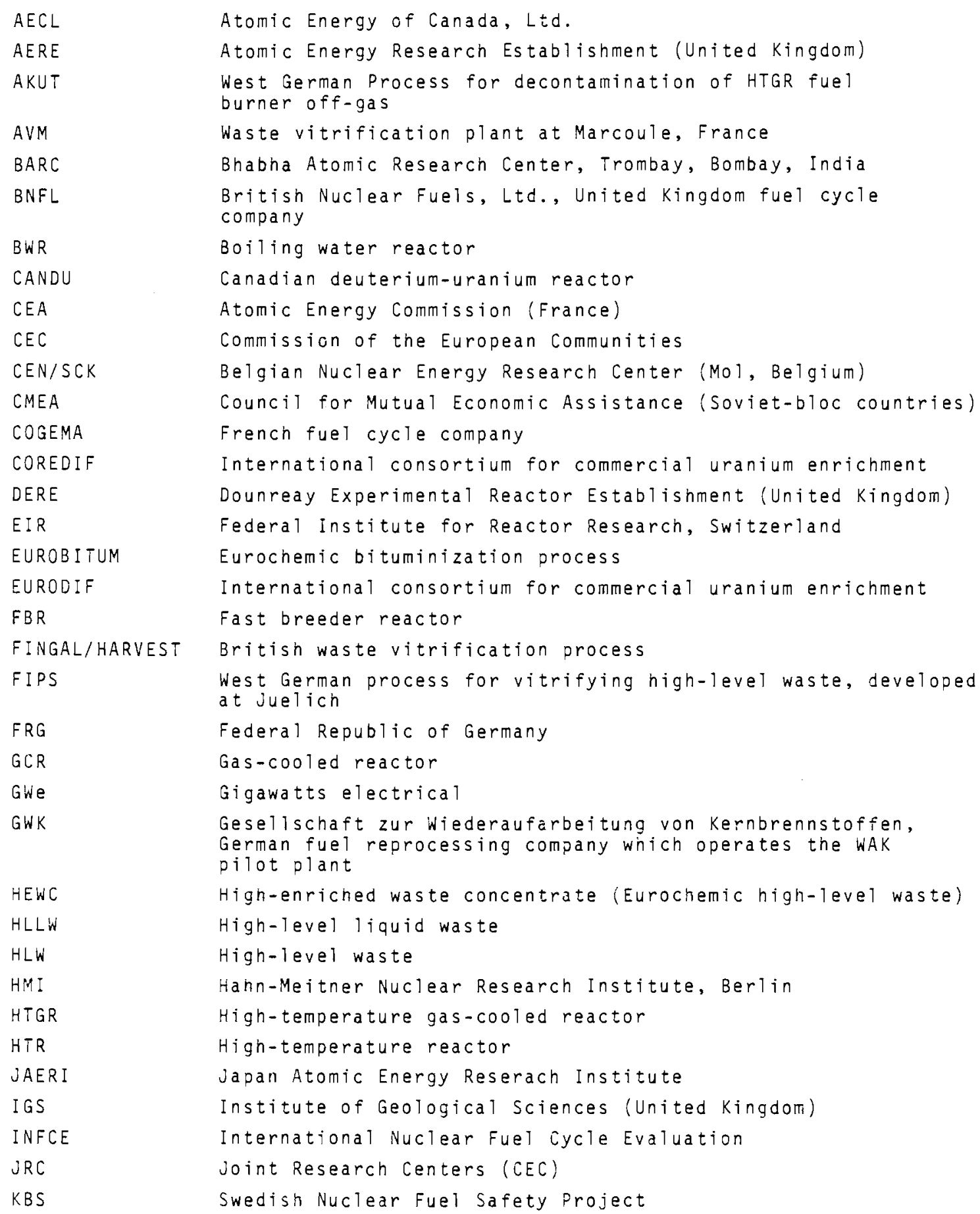




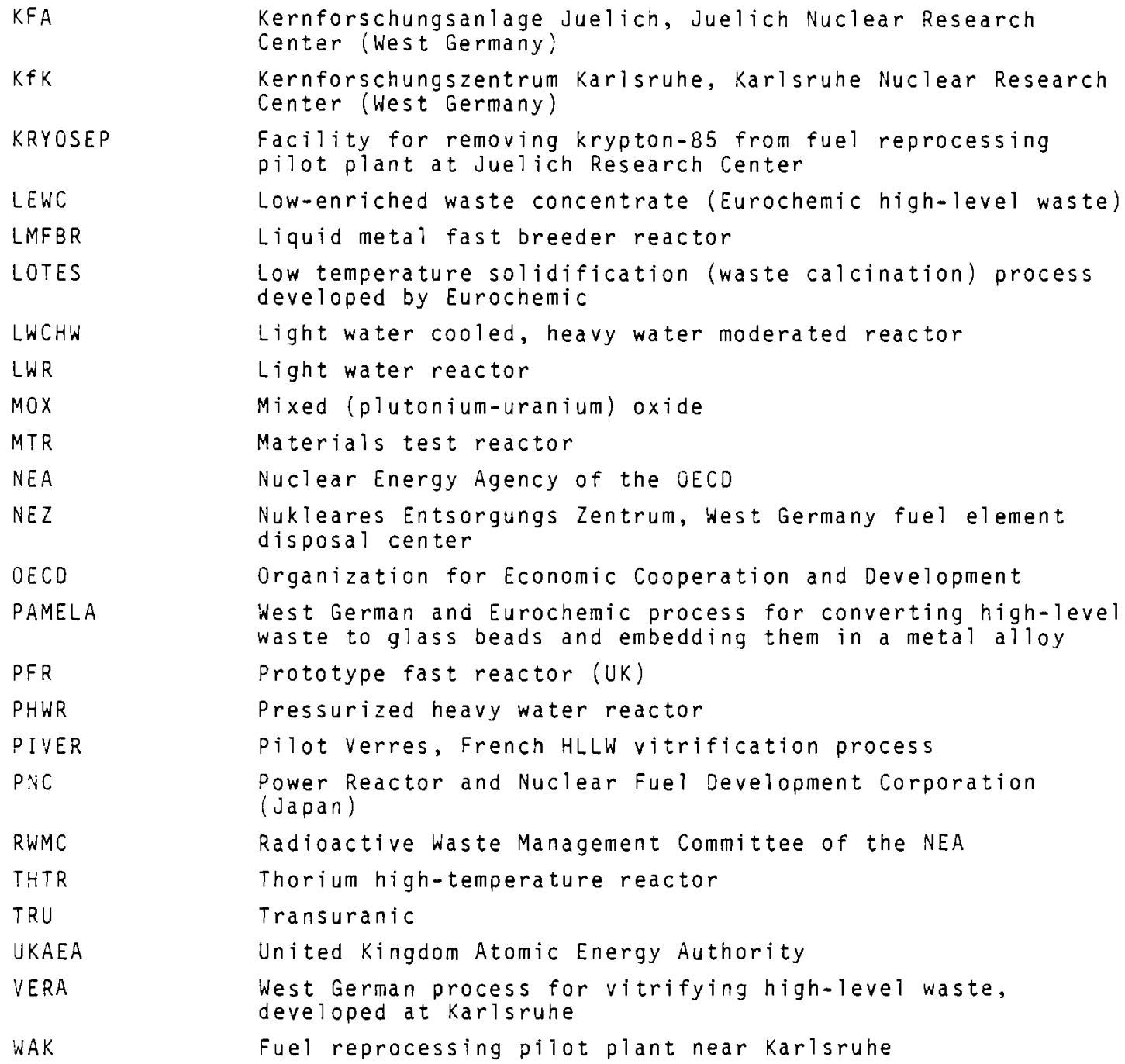




\section{SURVEY OF NATIONAL AND INTERNATIONAL RADIOACTIVE WASTE MANAGEMENT PROGRAMS}

\section{INTRODUCTION}

Many nations and international agencies are working to develop improved technology and industrial capability for nuclear fuel cycle and waste management operations. The effort in some countries is 1 imited to research in university laboratories on treating low-level waste from reactor plant operations. In other countries, national nuclear research institutes are engaged in major programs in a 11 phases of the fuel cycle and waste management, and there is a national effort to commercialize fuel cycle operations.

Since late 1976, staff members of Pacific Northwest Laboratory have been working under USERDA/DOE sponsorship to assemble and consolidate openly-available information on foreign and international nuclear waste management programs and technology. This report summarizes the information collected on the status of fuel cycle and waste management programs in selected countries making major efforts in these fields. This compilation attempts to provide current information as of the end of February 1978. The situation in many countries is changing rapidly, however, and the data presented may be outdated.

This report is divided into two parts. The first section summarizes in tabular form various national fuel cycle and waste management programs. The rest of the report gives a nation-by-nation overview of fuel cycle and waste management technologies. Included in this section are brief summaries on the activities of several international organizations: 


\section{TABLE SUMMARIES}

NUCLEAR POWER PROJECTIONS

The mid-February 1978 issue of Nuclear News (1) 1ists

34 nations as having committed nuclear power stations

(30 Mwe or greater). (a) Table 1 lists nuclear power

projections for these and six other countries plan-

ning for future nuclear commitment. 
TABLE 1. Nuclear Power Projections

\begin{tabular}{|c|c|c|c|c|c|c|c|}
\hline & & & We & & & & de \\
\hline Country & Conmit & tted $(a)$ & Pro & ected (Year) & Country & Cormitted $(a)$ & Projected (Year) \\
\hline Argentina & 0.9 & (PHWR) & 9 & $(2000)$ & Japan & $18 \quad(L W R)$ & (1985) \\
\hline Austria & 0.7 & $(L W R)$ & & & & $\begin{array}{l}0.3 \text { (LMFBR) } \\
0.2 \text { (GCR) }\end{array}$ & $(1990)$ \\
\hline Belgium & 5.5 & $(L W R)$ & & & & $0.2(\mathrm{LWCHW})$ & \\
\hline Brazi] & 3.1 & $(L W R)$ & & $\begin{array}{l}(1990) \\
2000)\end{array}$ & Korea (So.) & $\begin{array}{ll}1.2 & (\mathrm{LWR}) \\
0.6 & (\mathrm{PHWR})\end{array}$ & $\begin{array}{c}4 \quad(1986) \\
40-46 \text { plants }\end{array}$ \\
\hline Bulgaria & 1.8 & (LWR) & 7. & $(1990)$ & & & $(2000)$ \\
\hline Canada & 11.9 & (PHWR) & & $(2000)$ & Kuwait & & $\begin{array}{l}6+\text { desalination } \\
\text { capacity }\end{array}$ \\
\hline Chile & & & 0. & $(1988)$ & & & $(2000)$ \\
\hline Cuba & 1.7 & (LWR) & Sev & ral reactors & Luxembourg & $1.3(L W R)$ & \\
\hline & & & & $(1990)$ & Mexico & $1.3(\mathrm{LWR})$ & $10 \quad(1990)$ \\
\hline Czechos lovakia & $\begin{array}{l}1.8 \\
0.1\end{array}$ & $\begin{array}{l}(\text { LWR }) \\
\text { (GCHWR) }\end{array}$ & 12 & $(1990)$ & Nether lands & 0.5 (LWR) & $3.5(?)$ \\
\hline Egypt & 0.6 & (LWR) & 7 & $(2000)$ & New Zealand & & $1.2(?)$ \\
\hline Finland & 2.2 & (LWR) & & $(1985)$ & Pakistan & 0.1 (PHWR) & $\begin{array}{cc}4.8 & (1990) \\
16^{-19000)} & (2000)\end{array}$ \\
\hline France & $\begin{array}{r}37.2 \\
2.2\end{array}$ & $\begin{array}{l}\text { (LWR) } \\
\text { (GCR) }\end{array}$ & 40 & $(1985)$ & Philippines & $1.2(\mathrm{LWR})$ & $3.9(2000)$ \\
\hline & 0.07 & (GCHWR) & & & Poland & $0.4(L W R)$ & $8 \quad(1990)$ \\
\hline & 1.4 & (LHFBR) & & & Rumania & $0.4(L W R)$ & +16 PHWR \\
\hline Germany (East) & 2.7 & $(L W R)$ & & & & & $(2000)$ \\
\hline Germany (West) & 26.3 & (LWR) & 30 & $(1985-6)$ & South Africa & $1.8(L W R)$ & $(2000)$ \\
\hline & $\begin{array}{l}0.3 \\
0.3 \\
0.05\end{array}$ & $\begin{array}{l}\text { (LMFBR) } \\
\text { (THTR) } \\
\text { (PHWR) }\end{array}$ & & & Spain & $\begin{array}{r}15.6 \text { (LWR) } \\
0.5 \text { (GCR) }\end{array}$ & \\
\hline Hungary & 1.8 & (LWR) & & $(1990)$ & Sweden & 9.4 (LWR) & \\
\hline & & & 12 & $(2000)$ & Switzerland & 5.9 (LWR) & \\
\hline India & 0.4 & (LWR) & & (1990) & Taiwan & 4.9 (LWR) & \\
\hline & 1.3 & & & $(2000)$ & Turkey & & $4.4(1990)$ \\
\hline Iran & 4.2 & $(L W R)$ & & $\begin{array}{l}(1992) \\
(2000)\end{array}$ & $\begin{array}{l}\text { United } \\
\text { Kingdom }\end{array}$ & $\begin{aligned} 11.4 & (G C R) \\
0.1 & (H W L W R)\end{aligned}$ & $100 \quad(2000)$ \\
\hline Israel & & & & (with de- & & 0.3 (LMFBR) & \\
\hline & & & & $\begin{array}{l}\text { lination } \\
\text { Dacity) }\end{array}$ & $\begin{array}{l}\text { United } \\
\text { States }\end{array}$ & 197 & \\
\hline Italy & $\begin{array}{l}5.1 \\
0.2 \\
0.04\end{array}$ & $\begin{array}{l}\text { (LWR) } \\
\text { (GCR) } \\
\text { (LWCHW) }\end{array}$ & $9-1$ & $(1985)$ & U.S.S.R. & $\begin{aligned} 5.0 & (\mathrm{LWR}) \\
14.9 & (\mathrm{LGR}) \\
1.0 & (\mathrm{LMFBR})\end{aligned}$ & (?) \\
\hline & & & & & Yugoslavia & 0.6 (LWR) & $0.6(1987)$ \\
\hline
\end{tabular}

(a) Operable, under construction or on order. 
NUCLEAR FUEL CYCLE PROGRAMS IN SELECTED COUNTRIES

Table 2 i ists countries with significant R\&D effort in one or more fuel cycie and/or waste management areas and indicates the areas in which each country is working. 
TABLE 2. Nuclear Fuel Cycle Programs in Selected HLLW Countries

\begin{tabular}{|c|c|c|c|c|c|c|c|c|c|c|c|c|c|}
\hline Country & $\begin{array}{l}\text { Page } \\
\text { No. }\end{array}$ & $\begin{array}{l}\text { Power } \\
\text { Genera- } \\
\text { tion } \\
\end{array}$ & $\begin{array}{l}U \\
\text { Enrich- } \\
\text { ment } \\
\end{array}$ & $\begin{array}{c}\text { Fuel } \\
\text { Fabri- } \\
\text { cation } \\
\end{array}$ & $\begin{array}{l}\text { Fuel } \\
\text { Repro- } \\
\text { cessing }\end{array}$ & HLLW & $\begin{array}{l}\text { Non- } \\
\text { HLLWH }\end{array}$ & IRU & Hulls & $\begin{array}{l}\text { Soilid } \\
\text { Wastes }\end{array}$ & $\begin{array}{c}\text { Volatile } \\
\text { Radio- } \\
\text { nuclides } \\
\end{array}$ & $\begin{array}{l}\text { Waste } \\
\text { Isola- } \\
\text { tion } \\
\end{array}$ & $\begin{array}{l}\text { Safety } \\
\text { Assess- } \\
\text { ment } \\
\end{array}$ \\
\hline Argentina & 14 & PHWR & & $x$ & & & $x$ & & & & & & \\
\hline Australid & 14 & & $\begin{array}{l}\text { Gas } \\
\text { Cent. }\end{array}$ & & & & $x$ & & & & & & \\
\hline Austria & 15 & LWR & & & & $x$ & $x$ & & & & & Geol. & $x$ \\
\hline Belgium & 16 & $\frac{\text { LWR }}{\text { LMFBR }}$ & & $\frac{U}{U-P u}$ & LWR & & $x$ & $x$ & & $x$ & $x$ & Geol. & $x$ \\
\hline Brazil & 17 & LWR & $\begin{array}{l}\text { Becker } \\
\text { Nozzle }\end{array}$ & $x$ & LWR & & & & & & & & \\
\hline Canada & 17 & PHWR & & $\frac{U}{U-P u}$ & $x$ & $\bar{x}$ & $\bar{x}$ & & & $\bar{x}$ & $\bar{x}$ & Geol. & $\bar{x}$ \\
\hline Denmark & & & & & & & & & & & & Geor. & \\
\hline Eurochemic & 39 & & & & & $x$ & $x$ & & $x$ & $x$ & & & \\
\hline $\begin{array}{l}\text { European } \\
\text { Community (CEC) }\end{array}$ & & & & & & $x$ & $x$ & $x$ & & & & $x$ & $x$ \\
\hline Finland & & LWR & & & & & $x$ & & & $x$ & & $\begin{array}{l}\text { Shallow } \\
\text { Burial }\end{array}$ & $x$ \\
\hline France & 19 & $\frac{\frac{L W R}{L M F B R}}{\frac{L M R}{G C R}}$ & $\begin{array}{l}\text { Diff. } \\
\text { Chem. } \\
\text { Exch. }\end{array}$ & $\frac{U}{U-P u}$ & $\frac{\frac{U \text { Metal }}{L W R}}{F B R}$ & $x$ & $x$ & $x$ & $x$ & $x$ & $x$ & Geol. & $x$ \\
\hline $\begin{array}{l}\text { Germany, East } \\
\text { (Dem. Rep.) }\end{array}$ & & LWR & & & & & & & & & & Geol. & \\
\hline $\begin{array}{l}\text { Germany, West } \\
\text { (Fed. Rep.) }\end{array}$ & 22 & $\frac{L W R}{L M F B R}$ & $\begin{array}{l}\text { Gas } \\
\frac{\text { Cent. }}{\text { Becker }}\end{array}$ & $\frac{U}{U-P_{U}}$ & LWR & $x$ & $x$ & $x$ & $x$ & $x$ & $x$ & Geol. & $x$ \\
\hline India & 26 & $\frac{\frac{P H W R}{L W R}}{\frac{L W R}{F B R}}$ & & $x$ & LWR & $x$ & $x$ & $x$ & $x$ & & & Geol. & $x$ \\
\hline Iran & 27 & LWR & & & & & & & & & & & \\
\hline Italy & 27 & $\frac{\frac{L W R}{G C R}}{\frac{G M F B R}{L M R}}$ & & $\frac{U}{U-T h-P U}$ & $\frac{L W R}{M T R}$ & $x$ & $\bar{x}$ & $x$ & & $x$ & & Geol. & $\bar{x}$ \\
\hline Japan & 29 & $\frac{\frac{L W R}{L M F B R}}{\frac{L M C R}{G C R}}$ & $\begin{array}{l}\text { Gas } \\
\text { Cent. }\end{array}$ & $\frac{U}{U-P U}$ & LWR & $x$ & $x$ & $x$ & & $x$ & $x$ & $\frac{\text { Geol. }}{\text { Seabed }}$ & $x$ \\
\hline Mexico & & LWR & & $\frac{U}{U-P_{U}}$ & LWR & & & & & & & & \\
\hline Netherl ands & & $\frac{L W R}{[M F B R}$ & $\begin{array}{l}\text { Gas } \\
\text { Cent. }\end{array}$ & & & & $x$ & & & $x$ & & Geol. & $x$ \\
\hline Pakistan & & PHWR & & & $x$ & & & & & & & & \\
\hline South Africa & & LWR & $\begin{array}{l}\text { Vortex } \\
\text { Tube }\end{array}$ & & & & & & & & & & \\
\hline Spain & 30 & $\frac{L W R}{G C R}$ & & $x$ & $x$ & $x$ & $x$ & & & $x$ & & Geol. & \\
\hline Sweden & 31 & LWR & & & & $x$ & & $x$ & & $x$ & & Geol. & $x$ \\
\hline Switzerland & 32 & LWR & & & & & & & & & & Geol. & $x$ \\
\hline $\begin{array}{l}\text { United } \\
\text { Kingdom }\end{array}$ & 32 & $\frac{\text { GCR }}{\text { LMFBR }}$ & $\begin{array}{l}\frac{\text { Diff. }}{\text { Gas }} \\
\text { Cent. }\end{array}$ & $\frac{U}{U-P_{u}}$ & $\frac{\operatorname{LinR}}{\operatorname{LMFBR}}$ & $x$ & $x$ & $x$ & $x$ & $x$ & $x$ & $\frac{\text { Geol. }}{\text { Seabed }}$ & $x$ \\
\hline $\begin{array}{l}\text { United } \\
\text { States }\end{array}$ & & $\frac{\frac{L W R}{\text { HTGR }}}{\text { LMFBR }}$ & $\frac{\text { Diff. }}{\frac{\text { G.C. }}{\text { Laser }}}$ & $\frac{U}{U-P u}$ & $x$ & $x$ & $\bar{x}$ & $x$ & $x$ & $x$ & $x$ & $\frac{\text { Geol. }}{\text { Seabed }}$ & $x$ \\
\hline USSR & 35 & $\frac{\frac{L W R}{L W G R}}{\frac{L A G B R}{L A F B R}}$ & $x$ & $x$ & $x$ & $x$ & $x$ & $x$ & & $x$ & & Geol. & $x$ \\
\hline
\end{tabular}




\section{URANIUM ENRICHMENT}

Table 3 identifies nations with active uranium enrichment production and/or development programs. There is a

strong trend away from the gaseous diffusion process in the construction of new plants. The URENCO-CENTEC consortium (United Kingdom, Netherlands, Federal Republic of Germany) has recently started up gas centrifuge plants in England and Holland, and other nations are developing gas centrifuge capability. German (FRG) scientists have developed the Becker "Nozzle" process, which is to be demonstrated in a Brazilian pilot plant currently planned as a Brazil-FRG joint venture. France has announced plans for a small plant to demonstrate a chemical exchange process, and South Africa's vortex tube process is in the pilot plant stage. 
TABLE 3. Uranium Enrichment

\begin{tabular}{|c|c|c|}
\hline Nation & Process & Status \\
\hline Australia & Gas Centrifuge & $\begin{array}{l}\text { R\&D at Lucas Heighes; negotiations with } \\
\text { Urenco and Japan to purchase technology }\end{array}$ \\
\hline Brazil & $\begin{array}{l}\text { Becker Nozzle } \\
\text { Process }\end{array}$ & $\begin{array}{l}\text { Planning to build pilot plant in partnership } \\
\text { with West Germany }\end{array}$ \\
\hline \multirow[t]{2}{*}{ France } & Gaseous Diffusion & $\begin{array}{l}\text { Partnership in Eurodif and Coredif consortia } \\
\text { for commercial enrichment }\end{array}$ \\
\hline & Chemical Exchange & $\begin{array}{l}\text { R\&D; pianning to build demonstration-scale } \\
\text { plant }\end{array}$ \\
\hline \multirow{2}{*}{$\begin{array}{l}\text { Germany } \\
\text { (FRG) }\end{array}$} & Gas Centrifuge & R\&D; member of Urenco \\
\hline & $\begin{array}{l}\text { Becker Nozzle } \\
\text { Process }\end{array}$ & $\begin{array}{l}\text { R\&D; supplying technology to Brazil for } \\
\text { Becker pilot plant }\end{array}$ \\
\hline Japan & Gas Centrifuge & R\&o; planning to build pilot plant \\
\hline Netherlands & Gas Centrifuge & Partnership in Urenco; plant at Almelo \\
\hline South Africa & Yortex Tube & R\&D; pilot plant \\
\hline United Kingdom & $\begin{array}{l}\text { Gaseous Diffusion } \\
\text { Gas Centrifuge }\end{array}$ & $\begin{array}{l}\text { Plant at Capenhurst } \\
\text { Partnership in Urenco, plant at Capenhurst }\end{array}$ \\
\hline United States & $\begin{array}{l}\text { Gaseous Diffusion } \\
\text { Gas Centrifuge } \\
\text { Laser }\end{array}$ & $\begin{array}{l}\text { Production plants in operation } \\
\text { Planning cormercia! plant } \\
\text { R\&D }\end{array}$ \\
\hline USSR & Gaseous Diffusion & Production plants in operation \\
\hline $\begin{array}{l}\text { Belgium, Iran, } \\
\text { Italy, Spain }\end{array}$ & Gaseous Diffusion & Partners with France in Eurodif and Coredif \\
\hline
\end{tabular}




\section{FUEL FABRICATION}

In nations with private-enterprise economic systems, uranium fuels for power stations are generally fabricated by private industry, and manufacturing capability is widespread. A number of nations are also working toward plutonium recycle, to fuel LWRs and/or fast breeders. Plutonium-uranium mixed oxide (MOX) fuel fabrication is generally handled by government plants.

\section{FUEL REPROCESS ING}

Nations with spent fuel reprocessing R\&D programs, reprocessing capability, or current aspirations to develop these programs are identified in Table 4 . Some countries (e.g., France and England) are planning to handle spent fuel for other nations, some are striving to become or remain self-sufficient, and a few plan to buy reprocessing services elsewhere. A number of the smaller countries, which would not find it economical to build and operate their own plants, would welcome partnership in a regional fuel cycle center or in an international fuel reprocessing consortium. 
TABLE 4. Fuel Reprocessing

\begin{tabular}{|c|c|c|c|}
\hline Nation & Plant & Status & Major Miles tones \\
\hline \multirow[t]{2}{*}{ Beigium } & $\begin{array}{l}\text { Eurochemic (Mol, } \\
\text { international spon- } \\
\text { sorship) }\end{array}$ & $\begin{array}{l}60 \text { tonne/yr. Shut down by Eurochemic } \\
\text { in } 7974 \text {. Takeover by Belgium } \\
\text { planned. }\end{array}$ & $\begin{array}{l}\text { Startup by Belgium-- } \\
1982-1983\end{array}$ \\
\hline & Belgoprocess (Mol) & $\begin{array}{l}1500 \mathrm{~kg} / \text { day plant is under considera- } \\
\text { tion }\end{array}$ & \\
\hline Brazil & Pilot plant & $\begin{array}{l}10 \mathrm{~kg} \mathrm{U} / \text { day. Conceptual study done } \\
\text { by KEWA/Unde. }\end{array}$ & \\
\hline \multirow[t]{5}{*}{ France } & SAP (Marcoule) & $\begin{array}{l}25 \mathrm{~kg} / \text { day operational pilot plant-- } \\
\text { used for R\&D. }\end{array}$ & \\
\hline & Up ${ }_{1}$ (Marcoule) & $\begin{array}{l}900-1200 \text { tonne/yr, operational, used } \\
\text { for } U \text { metal fuels. }\end{array}$ & \\
\hline & AT-I (La Hague) & $\begin{array}{l}200 \mathrm{~kg} / \mathrm{yr} \text { operational pilot plant } \\
\text { (MOX fue 1). Reprocessing breeder } \\
\text { fuels. }\end{array}$ & \\
\hline & $U P_{2}$ (La Hague) & $\begin{array}{l}1000 \text { tonne/yr, operational, used to } \\
\text { reprocess gas reactor fue } 15 \text {; now has } \\
\text { a } 400 \text { tonne/yr head end for LWR } \\
\text { fuels. }\end{array}$ & \\
\hline & $U P_{3}$ (La Hague) & $\begin{array}{l}\text { Dual-line reprocessing plant for LWR } \\
\text { fuels. First line ( } 800 \text { tonne/yr) is } \\
\text { to service foreign customers. }\end{array}$ & $\begin{array}{l}\text { Startup of first } \\
\text { line--1985 } \\
\text { Startup of second } \\
\text { line--1987 }\end{array}$ \\
\hline \multirow[t]{3}{*}{$\begin{array}{l}\text { Germany } \\
\text { (West) }\end{array}$} & WAK (Leopoldshafen) & $\begin{array}{l}40 \text { tonne/yr operational pilot plant } \\
\text { for R\&D. }\end{array}$ & \\
\hline & KEWA (Gorleben) & $\begin{array}{l}1400 \text { tonne } / y r \text { commercial plant for } \\
\text { LWR fuels. }\end{array}$ & Startup-- 1990 \\
\hline & JUPITER (Jülich) & $2 \mathrm{~kg} /$ day pilot plant for HTGR fue 1 & Startup-- 1980 \\
\hline \multirow[t]{3}{*}{ India } & Trombay & $\begin{array}{l}60 \text { tonne/yr operational pilot plant } \\
\text { for } U \text { metal or oxide fuels. }\end{array}$ & \\
\hline & Tarapur & 100 tonne/yr, oxide fuels & $\begin{array}{l}\text { Precomissioning } \\
\text { trials during } 1977\end{array}$ \\
\hline & Kalpakkam & $\begin{array}{l}\text { Planned-- to handle CANDU and thorium } \\
\text { FBR fuels. }\end{array}$ & \\
\hline \multirow[t]{3}{*}{ Italy } & EUREX (Saluggia) & $\begin{array}{l}30 \mathrm{~kg} / \text { day, operationa } 1 \text {, MTR and } \\
\text { oxide fuels. }\end{array}$ & \\
\hline & ITREC (Trisaia) & $\begin{array}{l}15 \mathrm{~kg} / \text { day, operational, }{ }^{233} \mathrm{U}-\mathrm{Th} \text { and } \\
\text { Pu-U fuels. }\end{array}$ & \\
\hline & Commercial & $1000-1500$ tonne/yr. & Startup--iate 1990s \\
\hline \multirow[t]{2}{*}{ Japan } & Tokai & $\begin{array}{l}210 \text { tonne/yr, operational, oxide } \\
\text { fuels. }\end{array}$ & Startup--late 1977 \\
\hline & $\begin{array}{l}\text { Commercia) } \\
(2 \text { plants })\end{array}$ & Plants are planned. & $\begin{array}{l}\text { Startup of first-- } \\
\text { late } 1980 \mathrm{~s}\end{array}$ \\
\hline Pakistan & Commercial & Capacity--100 tonne/yr range & \\
\hline Spain & & $\begin{array}{l}\text { Lab-scale, } 2000 \mathrm{~kg} / \mathrm{yr}--i n \text { design } \\
\text { stage. }\end{array}$ & $\begin{array}{l}\text { Commercial plant-- } \\
\text { late } 1990 \text { s }\end{array}$ \\
\hline \multirow[t]{3}{*}{ United Kingdom } & Windscale & $\begin{array}{l}1500-2500 \text { tonne/yr, GCR fue } 1 \mathrm{~s} \text {; the } \\
\text { plant has a new } 400 \text { tonne/yr head } \\
\text { end for oxide fuels. }\end{array}$ & \\
\hline & THORP (Windscale) & $\begin{array}{l}1200 \text { tonne/yr, for oxide fuels. In } \\
\text { planning stages. }\end{array}$ & Startup--mid 1980s \\
\hline & Dounreay & $\begin{array}{l}10 \text { tonne/yr operational pilot plant, } \\
\text { FBR (MOX) fueis. }\end{array}$ & \\
\hline \multirow[t]{3}{*}{ United States } & $\begin{array}{l}\text { NFS (hest Valley, } \\
\text { NY) }\end{array}$ & $\begin{array}{l}300 \text { tonne/yr oxide fuels; snut down } \\
\text { (operated } 1956-1972 \text { ). }\end{array}$ & \\
\hline & MFRP (Morris, IL) & $\begin{array}{l}300 \text { tonne/yr oxide fuels. Inoper- } \\
\text { able--providing fuel storage. }\end{array}$ & \\
\hline & AGNS (Barnweil, SC) & $\begin{array}{l}1500 \text { tonne/yr, oxide fuels. Plant } \\
\text { constructed, awating decision con- } \\
\text { cerning U.S. reprocessing. }\end{array}$ & \\
\hline \multirow[t]{2}{*}{ USSR } & $\begin{array}{l}\text { Klopin Radium } \\
\text { Institute }\end{array}$ & $\begin{array}{l}\text { Experimental (several } \mathrm{kg} / \text { jay) } \\
\text { reprocessing facility. }\end{array}$ & \\
\hline & & $\begin{array}{l}5 \text { tonne/day plant for oxide fueis } \\
\text { is reportediy under construction. }\end{array}$ & Startup--about 1980 \\
\hline
\end{tabular}




\section{HLLW SOLIDIFICATION}

National and international programs to develop HLLW solidification technology are listed in Table 5. Several countries have processes in advanced stages of development and are working toward achieving full-scale process demonstration in the late 1970 s and 1980s. France is striving for international acceptance of their AVM (Marcoule) vitrification process and has succeeded to the extent that AVM is to be used to solidify most of the existing Eurochemic HLLW. Also, FRG plans to use AVM as the reference process for pending vitrification plant licensing applications in Germany. 


\section{TABLE 5. HLLW Solidification}

\begin{tabular}{|c|c|}
\hline Nation & ess \\
\hline Canada (Whiteshell) & Conversion of thorium-CANDU fuel cycie wastes to glass or ceramic. \\
\hline Eurochemic (Mol, Belgiun) & $\begin{array}{l}\text { LOTES process: stirred-fluidized bed (continuous), process } \mathrm{AlFO}_{4} \\
\text { waste granules (Can handle high Al-high Na feeds). } \\
\text { vitromet process: incorporates waste granuies or glass beads } \\
\text { into lead alloy matriz. }\end{array}$ \\
\hline France (Marcoule) & $\begin{array}{l}\text { PIVER pilot plant (batch): pot calciner-melter, drained through } \\
\text { a freeze-yalve. produces borosilicate giass. Maximum capacity: } \\
4 \mathrm{~kg} \text { glass/hr per unit. } \\
\text { AVM demonstration plant (continuous): rotating tube calciner; } \\
\text { Inconel melter drained through freeze valve. (AvM plant to be } \\
\text { built at Mol to solidify Eurochemic HLLW.) }\end{array}$ \\
\hline France (La Hague) & AVH production plant (continuous); AVM process. \\
\hline FRG (Karlsruhe) & $\begin{array}{l}\text { VERA pilot plant (nonradioactive) } \\
\text { 1. Steam-heated spray calciner coupled to a metallic meiter; } \\
\text { bottom drain produces borosilicate glass. } \\
\text { 2. Liquid-or spray-fed ceramic melter (continuously). Pro- } \\
\text { duces borosilicate giass. Capacity-- } 302 \text { feed/hr. }\end{array}$ \\
\hline FRG (Jülich) & $\begin{array}{l}\text { FIPS hot cell unit (semicontinuous): drum dryer coupled to } \\
\text { rising-level, in-pot melter. Cesigned to convert HIGR fuel } \\
\text { reprocessing waste to borosilicate glass or ceramic capacity-. } \\
\text { i kg glass/hr. } \\
\text { FIPS pilot plant. Capacity--10 kg glass/hr. }\end{array}$ \\
\hline FRG (Geisenberg A.G.) & $\begin{array}{l}\text { PAMELA process pilot plant (continuous): ceramic calciner- } \\
\text { me!ter coupled with a glass bead-maker. Produces phosphate } \\
\text { glass beads which can be incorporated in a metal matrix to } \\
\text { form "vitromet." }\end{array}$ \\
\hline $\begin{array}{l}\text { India (Trombay and } \\
\text { Tarapur) }\end{array}$ & $\begin{array}{l}\text { Tarapur vitrification plant (semicontinuous): pot calcine and } \\
\text { melt; drain to waste canister. Capacity }--25 \mathrm{l} / \mathrm{hr} \mathrm{HLLH} \text {. }\end{array}$ \\
\hline $\begin{array}{l}\text { Italy (CNEN--Casaccia and } \\
\text { URC--Ispra) }\end{array}$ & $\begin{array}{l}\text { ESTER bench-scale unit (batch): (Inconel pot). Capacity--2 kg } \\
\text { giass/run. }\end{array}$ \\
\hline Lapan (PNC) & $\begin{array}{l}\text { Fluidized-bed calcination, followed by vitrification or hot- } \\
\text { pressing. }\end{array}$ \\
\hline $\begin{array}{l}\text { Japan (JAERI) } \\
\text { Spain (Juan Vigon) }\end{array}$ & $\begin{array}{l}\text { Calination and vitrification of waste-loaded zeolites. } \\
\text { HLLW solidification. }\end{array}$ \\
\hline Sweden (ASEA-Atom) & $\begin{array}{l}\text { Hot isostatic pressing to encapsulate fuel or convert calcine to } \\
\text { ceramics. }\end{array}$ \\
\hline $\begin{array}{l}\text { Sweden (Royal inst. of } \\
\text { Teen.) }\end{array}$ & Fission product absorpticn intc titanate ion exchange resins. \\
\hline United Kingdom (Harwell) & $\begin{array}{l}\text { FINGAL/HARVEST (semicontinuous): rising-level, in-canister cal- } \\
\text { cination and vitrification. Product--borosilicate glass } \\
\text { cylinders. }\end{array}$ \\
\hline $\begin{array}{l}\text { Linl ted Kingdom } \\
\text { (Windscale) }\end{array}$ & $\begin{array}{l}\text { FINGAL/HARVEST process (semicont inuous): } \\
\text { Windscale hot ptlot piant }(12 / \mathrm{hr} \text { feed) } \\
\text { windscale demonstration plant } \\
\text { Windscale production plant }\end{array}$ \\
\hline United Kingdom (Dounreay) & $\begin{array}{l}\text { Vitrification plant for HLLW from FBR fuels (process not } \\
\text { selected). Required capacity: } 30 \mathrm{l} / \mathrm{hr} \text { (HLLW). }\end{array}$ \\
\hline $\begin{array}{l}\text { United States (ICPP, } \\
\text { (Idaho Falls) }\end{array}$ & Fluidized bed calcination with in-bed compustion. \\
\hline $\begin{array}{l}\text { United States (PNL, } \\
\text { Richiand) }\end{array}$ & $\begin{array}{l}\text { ORNL pot calcination process: calcination in the storage } \\
\text { canister. } \\
\text { ORNL rising-levei glass process. } \\
\text { BNL phosphate glass process: Dlatinum calciner-melter. }\end{array}$ \\
\hline \multirow[t]{4}{*}{$\begin{array}{l}\text { United States (PNL, } \\
\text { Richland) }\end{array}$} & Spray calciner/in-can meìter. Capacity--50 kg/hr glass. \\
\hline & $\begin{array}{l}\text { Fluidized bed calciner with in-bed combustion. } \\
\text { Joule-neated ceramic melter: } \\
\text { Engineering-scale unit }\end{array}$ \\
\hline & Full-scale develooment unit: \\
\hline & $\begin{array}{l}\text { Direct liquid-fed ceramic melter: } \\
\text { Engineering-scale unit } \\
\text { Full-scale developmental unit }(100 \mathrm{i} / \mathrm{hr} \text { feed })\end{array}$ \\
\hline USSR & $\begin{array}{l}\text { Single-stage ohosphate glass process (continuous): simultaneous } \\
\text { evaporation, calcinacion and vitrification in ceramic-lined } \\
\text { metal box. }\end{array}$ \\
\hline & $\begin{array}{l}\text { iwo-stage fluidized bed process semicontinuous): calcine in } \\
\text { fluidized bed; teit and store in concrete refractory crucible. }\end{array}$ \\
\hline
\end{tabular}

\author{
Status/Major Milestones \\ Laboratory studies in orogress. \\ All-steel test unit ( $10 \mathrm{l} / \mathrm{hr}$ feed) is operable. \\ Demonstrated with radioactive glass beads from FRG \\ PAMELA vitriffcation process. \\ Extensive process demonstration with Marcoule HLLW. \\ pilot plant now used for special work, e.g., FaR \\ waste treatment. \\ Capacity- $-40 \mathrm{x} / \mathrm{hr}$ feed $\left(150 \mathrm{~m}^{3} / \mathrm{yr}\right) ; 20 \mathrm{~kg} / \mathrm{hr}$ glass. \\ Startup--i978.
}

Startup--1982-1983.

Extensive cold process demonstration; hot-cell tests completed. iNo further work planned.

cold testing under way.

Process demonstration conducted with ERROCHEMIC HLLiN.

To handle waste from JUPITER MTGR fuel reprocessing pilot plant.

Process development:

Bead making--Jülich

Vitromet process--Eurochemic

Process pilot plant to be built at Mo1. Capacity30-40 $2 / \mathrm{hr}$ HLLH. Startup-- 1983

Startup--1979-1980. (Process developed by BARC at Trombayl.

Hot-cell tests at ispra; scaleup planned.

Demonstration facility planned. Startup--1986.

Lab-scale work.

Laboratory studies.

Laboratory studies.

Laboratory studies.

Hot demonstration with Hindscale HLLW achieved in FINGAL pilot plant. Process studies under way in cold HARVEST pilot piant.

Startup--7979.

Startup=-1966.

Startup-riate 1980 s.

In service.

Developed at ORNL; tested in WSEP at PIiL.

Developed at ORNL; :ested in WSEP.

Developed at Brookhaven; tested in WSEP.

Full-scale cold testing started. Active pilot plant startup: 1978; development complete by end of 1980.

Process development in piliot-scale unic completed: testing of scaled-up unit started.

Doerated from January 1975 (Capacity--60 kg/hr). Startup--1977.

Cold teses run. Canacity--30 i/nr HLLH.

Startup---?977

Coid pilot olant has sperated several years.

Cold pilo: plant tesis. Capacity- $-20 \mathrm{~kg} / \mathrm{hr}$ glass 


\section{GEOLOGIC WASTE ISOLATION}

Plans for geologic storage and/or isolation of spent fuel elements and solidified waste of various activity levels are being made by many countries, including nations which are contracting with France and the United kingdom for fuel reprocessing services. These contracts require return of solidified high-level wastes to the country of origin.

A few nations are also investigating the feasibility of seabed disposal of high-and non-high-level wastes.

National and international geologic waste isolation development programs are summarized in Table 6. 
TABLE 6. Geologic Waste Isolation

\begin{tabular}{|c|c|c|c|c|}
\hline Nation & Waste Type & $\begin{array}{l}\text { Formations } \\
\text { of Interest }\end{array}$ & Current Studies & Milestones \\
\hline Austria & $\begin{array}{l}\text { Spent fuels; } \\
\text { Misc. Wastes }\end{array}$ & Hard rock & $\begin{array}{l}\text { Site evaluation } \\
\text { Granite properties } \\
\text { Safety assessment }\end{array}$ & \\
\hline Belgium & $\begin{array}{l}\text { HLW } \\
\text { Non-HLW }\end{array}$ & Clay beds & $\begin{array}{l}\text { Site evaluation } \\
\text { Clay-bed properties } \\
\text { In situ studies--tunnel }\end{array}$ & $\begin{array}{l}\text { Pilot repository at } \\
\text { Mol for alpha and non- } \\
\text { HLW-- } 1981\end{array}$ \\
\hline Canada & $\begin{array}{l}\text { Spent fuels } \\
\text { HLW } \\
\text { Non-HLW }\end{array}$ & $\begin{array}{l}\text { Bedded salt } \\
\text { Plutonic rocks }\end{array}$ & $\begin{array}{l}\text { Site evaluation } \\
\text { In situ studies-- } \\
\text { Granite test site }\end{array}$ & $\begin{array}{l}\text { Commercial repository: } \\
\text { Site selection }--1981 \\
\text { Demonstration }--1986 \\
\text { Startup--2000 }\end{array}$ \\
\hline Denmark & Non-HLW & & Geologic survey & \\
\hline France & Alpha wastes & $\begin{array}{l}\text { Rock salt } \\
\text { Crystalline } \\
\text { rocks }\end{array}$ & $\begin{array}{l}\text { Geologic survey } \\
\text { Safety assessment } \\
\text { Oklo Phenomenon }\end{array}$ & $\begin{array}{l}\text { Pilot plant repository } \\
\text { (alpha wastes) }=1985\end{array}$ \\
\hline $\begin{array}{l}\text { Germany } \\
\text { (East) }\end{array}$ & Non-HLLW & Salt & $\begin{array}{l}\text { Repository development at } \\
\text { Bartens leben }\end{array}$ & \\
\hline $\begin{array}{l}\text { Germany } \\
\text { (West) }\end{array}$ & $\begin{array}{l}\text { Spent HTGR } \\
\text { fueis; Non- } \\
\text { HLLW; HLLW }\end{array}$ & Salt & $\begin{array}{l}\text { Sait Mine operation--Asse } \\
\text { mine } \\
\text { Safety assessment } \\
\text { Engineering for spent } \\
\text { fuel and HLW storage }\end{array}$ & $\begin{array}{l}\text { Commercial repository } \\
\text { at Gorleben--late } 1980 \text { s }\end{array}$ \\
\hline India & $\begin{array}{l}\text { HLW } \\
\text { Non-HLW }\end{array}$ & $\begin{array}{l}\text { Igneous rock } \\
\text { Sediments }\end{array}$ & $\begin{array}{l}\text { Site evaluation; proper- } \\
\text { ties of rocks }\end{array}$ & \\
\hline Iran & & & $\begin{array}{l}\text { UKAEA evaluation of dis- } \\
\text { posal in Iran }\end{array}$ & \\
\hline Ireland & Non-HLW & & Geologic survey & \\
\hline Italy & $H L W$ & $\begin{array}{l}\text { Clay } \\
\text { Salt }\end{array}$ & $\begin{array}{l}\text { Geologic survey; } \\
\text { In situ studies in clay } \\
\text { beds }\end{array}$ & $\begin{array}{l}\text { Pilot plant repository-- } \\
\text { mid ig80s }\end{array}$ \\
\hline Japan & HLW & Varied rock & $\begin{array}{l}\text { Geologic survey; safety } \\
\text { assessment }\end{array}$ & \\
\hline Nether 1 ands & Nan-HLW & Salt & $\begin{array}{l}\text { Geologic survey; safety } \\
\text { assessment }\end{array}$ & \\
\hline Spain & $\begin{array}{l}H L W \\
\text { Non-HLW }\end{array}$ & $\begin{array}{l}\text { Shale } \\
\text { Clay } \\
\text { Salt }\end{array}$ & $\begin{array}{l}\text { Non-HLW going into old } \\
\text { uranium mines; site } \\
\text { evaluation }\end{array}$ & $\begin{array}{l}\text { Pilot plant repository-- } \\
\text { late } 1980 \text { s }\end{array}$ \\
\hline Sweden & $\begin{array}{l}\text { Spent fuels } \\
\text { HLW } \\
\text { Non-HLW }\end{array}$ & $\begin{array}{l}\text { Hard rock } \\
\text { (granite) }\end{array}$ & $\begin{array}{l}\text { Field tests--Stripa mine; } \\
\text { Safety assessment }\end{array}$ & $\begin{array}{l}\text { Pilot plant repository-- } \\
\text { mid 1980s }\end{array}$ \\
\hline Switzerland & $\begin{array}{l}\text { HLW } \\
\text { Non-HLW }\end{array}$ & $\begin{array}{l}\text { Anhydrite; } \\
\text { Clay }\end{array}$ & $\begin{array}{l}\text { Site evaluation; safety } \\
\text { assessment; development } \\
\text { of test site for HLW }\end{array}$ & \\
\hline United Kingdom & & $\begin{array}{l}\text { Clay } \\
\text { Crystalline } \\
\text { rock }\end{array}$ & $\begin{array}{l}\text { Geologic survey; safety } \\
\text { assessment; site evalua- } \\
\text { tion }\end{array}$ & $\begin{array}{l}\text { Commercial repository- } \\
2000\end{array}$ \\
\hline United States & $\begin{array}{l}\text { Spent fuels } \\
\text { HLW } \\
\text { Non-HLW }\end{array}$ & $\begin{array}{l}\text { Salt } \\
\text { Shale } \\
\text { Igneous rock }\end{array}$ & $\begin{array}{l}\text { Site evaluation; safety } \\
\text { assessment; repository } \\
\text { engineering }\end{array}$ & $\begin{array}{l}\text { Pilot plant repositories -- } \\
\text { mid 1980s }\end{array}$ \\
\hline USSR & Non-HLW & Varied & $\begin{array}{l}\text { Direct injection under- } \\
\text { ground }\end{array}$ & \\
\hline CEC & HLW & & $\begin{array}{l}\text { Cataiog of potential } \\
\text { sites in member countries; } \\
\text { support work in Belgium } \\
\text { (clay), FRG (salt), UK } \\
\text { and France (crystalline } \\
\text { rock) }\end{array}$ & \\
\hline
\end{tabular}




\section{NATIONAL AND INTERNATIONAL PROGRAM OVERVIEWS}

Brief overviews of fuel cycle and waste management activities are provided
for the following nations and international organizations.
$\begin{array}{ll}\text { Argentina } & \text { Spain } \\ \text { Australia } & \text { Sweden } \\ \text { Austria } & \text { Switzerland } \\ \text { Belgium } & \text { United Kingdom } \\ \text { Canada } & \text { USSR } \\ \text { France } & \text { IAEA } \\ \text { Germany, Federal Republic } & \text { European Communities } \\ \text { of (FRG) } & \text { (including JRC-ISpra) } \\ \text { India } & \text { OECD/NEA } \\ \text { Iran } & \text { Eurochemic } \\ \text { Italy } & \text { CMEA } \\ \text { Japan } & \end{array}$

\section{ARGENTINA}

Nuclear Power

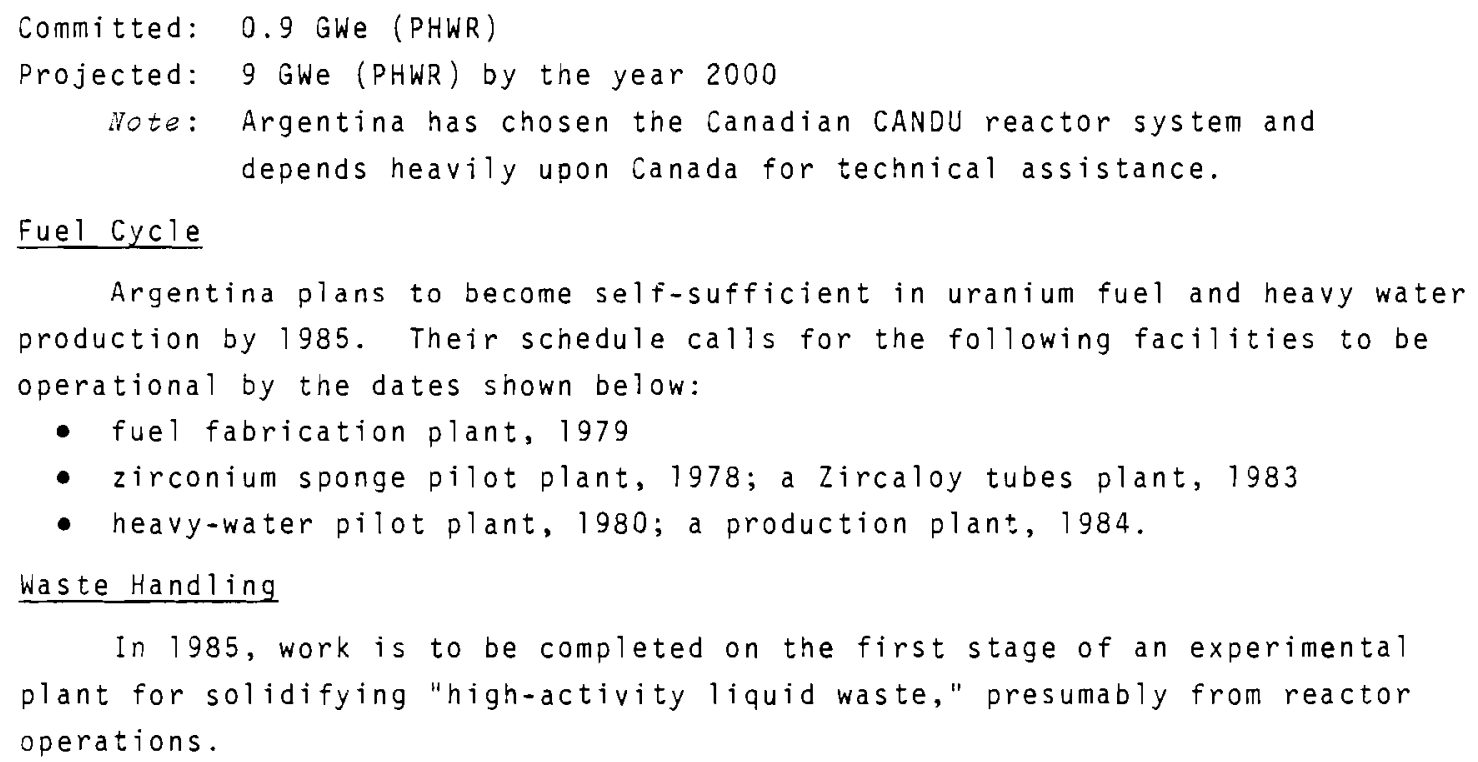

\section{AUSTRALIA}

Nuclear Power

None planned for Australia 


\section{Fuel cycle}

Australia possesses tremendous uranium reserves, and is developing a uranium mining, milling, and ore processing industry to exploit them. Uranium enrichment is also under consideration.

- Gas centrifuge R\&D is under way at the Lucas Heights (New South Waies) Research Establishment. The AEC has gas centrifuges operating in cascade.

- Australia is negotiating with other nations regarding the establishment of a uranium enrichment plant in Australia.

\section{Waste Management}

Waste handiing R\&D activities are primarily directed toward uranium ore processing wastes.

\section{$\underline{\text { AUSTRIA }}$}

Nuclear Power

Committed: A 730 MWe BWR at Tulinerfeld, near Vienna, which is nearly ready for its first fuel load

Note: The government has decided that until the waste disposal problem has been properly settled, the Tulinerfeld reactor will not be loaded with fuel and no other reactors will be ordered. Two additional reactors had been pianned.

\section{Fuel Reprocessing}

France's COGEMA and Austria's GKT utility have initiated a contract for the La Hague reprocessing plant to reprocess Austrian spent fuel. Austria will take back the vitrified waste and the recovered uranium. Recovered plutonium will be Austrian property, but will remain at La Hague.

HLLW Solidification, R\&D

Seibersdorf Research Centre: Vapor deposition techniques for coating HLW calcine granules with pyrolytic carbon in a fluidized bed are being developed. Waste Isolation, R\&D

Seibersdorf:

- survey of potential disposal sites

- tests of granite behavior when heated and irradiated

- safety assessment.

\section{Waste Isolation}

National Planning: At Iran's invitation, Austria and Iran are negotiating for disposal of Austria's wastes in the Iranian desert. 


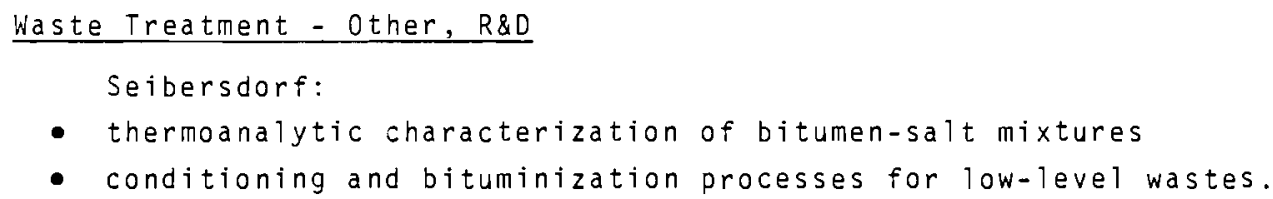

\section{BELGIUM}

Nuclear Power

Committed: 6 GWe (LWR) by 1983

Projected: In mid-1977, Belgian utilities projected 8 to 10 GWe nuclear power capacity by 1990. Present plans are very uncertain.

R\&D: Participation with West Germany and Holland in the 300 MW Kalkar FBR station (SNR) and with OECD in the Dragon HTR project.

Fuel Fabrication

Two companies located in Dessel manufacture nuclear fuel:

- Franco-Belge de Fabrication de Combustibles (FBFC), owned jointly by French and Belgian interests, manufactures uranium fuels

- Belgonucléaire fabricates uranium-plutonium fuels for LWRs and FBRs.

Fuel Reprocessing

Belgoprocess, owned jointly by the state and by synatom (a utilities organization), plans to take over and operate the 60 tonne/yr Eurochemic reprocessing plant. Decontamination of the plant, shut down since 1974, is nearly completed. Startup under Belgoprocess ownership is anticipated in 1982-1983. Construction of a second plant at the Mol site, rated at $1500 \mathrm{~kg} /$ day, is also under consideration.

Waste isolation

Belgium is working to develop and demonstrate technology for waste isolation in the claybeds beneath the Mol site. R\&D (CEN/SCK and the Geologic Service) includes:

- safety assessment and supporting studies

- in-situ tests (nonradioactive) in an existing tunnel near Antwerp

- development of plans for a pilot repository at Mol, to be operable in $1980-1981$.

Solid Waste Handling (Including TRU), R\&D

Nuclear Energy Research Centre, Mol-CEN/SCK: A high-temperature incinerator with a $150 \mathrm{~kg} / \mathrm{hr}$ capacity has given good results in cold tests and is being modified to handle TRU wastes. The incinerator operates at a temperature high enough to convert the ashes to a basalt-like slag. 
Non-HLLW Treatment

SCK/CEN operates a stirred-evaporator, batch bituminization plant for low-level wastes.

Eurochemic Activities

See the EUROCHEMIC summary, p. 39

\section{BRAZIL}

Nuclear Power

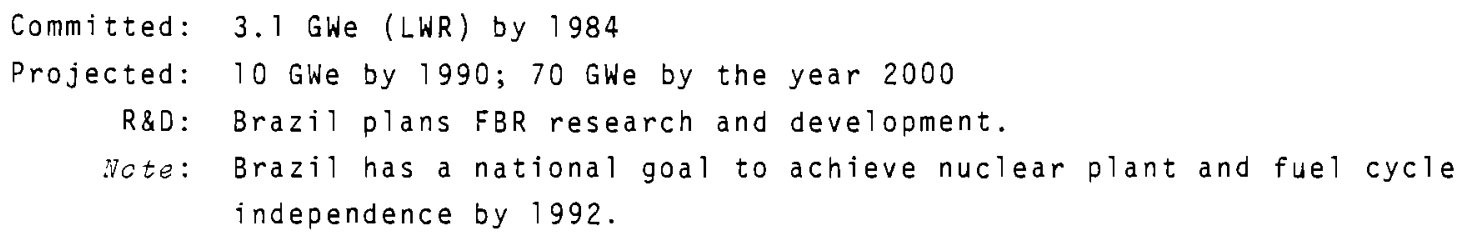

Fuel Cycle

Nuclebrás, the state-owned nuclear holding company, has become a partner with the Federal Republic of Germany (FRG) in a number of jointly-owned subsidiaries. One of these subsidiaries is to build and operate in Brazil a demonstration plant for the Becker "nozzle" (uranium enrichment) process, developed in Germany. Nuclebrás also plans to set up a 50 tonne/yr oxide fuel fabrication plant and a $10 \mathrm{~kg} \mathrm{U} / \mathrm{day}$ pilot reprocessing plant.

The developmental facilities are to be located at a new technology center near Santa Cruz.

\section{CANADA}

Nuclear Power

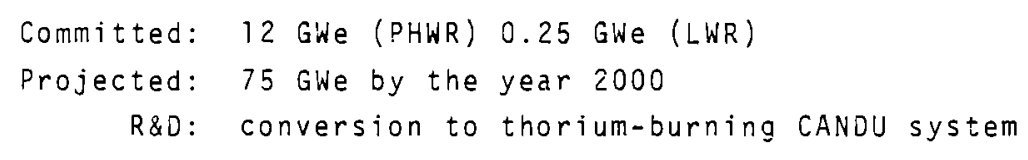

Fuel cycie

It has been past Canadian policy to store their spent CANDU fuels in waterfilled bays at the power generating sites, meanwhile deferring any serious work on reprocessing on the grounds that recycle was neither necessary nor economic. Current plans are to transfer spent fuels from the reactor fuel basins to a centralized interim storage facility at a Federal "Fual cycle Center."

Long-term Canadian Policy, however, assumes the eventual naed to recover plutonium and uranium from spent reactor fuels. Hence it is assumed that the Fuel cycle Center would include Federally-owned reprocessing, refabrication and waste treatment facilities. In order to acquire Pu-nanding experience, work 
was initiated recently at Whiteshell on reprocessing and Pu fuel fabrication. This effort was ordered stopped by the Canadian Government in October 1977 , pending the results of the INFCE study.

HLLW Solidification

Canadian policy also assumes the eventual need for geologic disposal of either solidified HLLW (probably as glass) or unreprocessed spent fuel elements. Workers at whiteshell are studying the incorporation of spent fuel wastes from the thorium fuel cycle into glasses and crystalline ceramic materials. The studies include development of solidification equipment and determination of the leaching and stability characteristics of solidified waste.

Spent Fuel and HLLW Storage/Isolation

Spent CANDU fuels have been stored at Chalk River in concrete-lined holes in the ground, and studies of spent fuel storage in surface concrete canisters are under way at Whiteshell.

Whiteshell is coordinating a Canadian program to demonstrate the use of a mined cavity for retrievable storage and, ultimately, disposal of solidified HLLW and/or spent fuel. The program calls for laboratory and field studies on hard rock and salt formations.

Geological and geophysical studies are concentrated in three branches of the Department of Energy, Mines and Resources: the Geological Survey of Canada, Can Met and the Earth Physics Branch. AECL also has contracts with the University of Quebec at Montreal for studies on serpentinite and with a mining consultant, Acres Consulting Services, for the preliminary conceptual design of the repository.

A test site has been established in a small granitic body (White Lake) approximately $110 \mathrm{~km}$ northwest of 0 ttawa to test equipment and theoretical concepts being developed for the hard rock repository concept.

The schedule for providing a licensed repository calls for site selection by 1981 , construction of the demonstration facility by 1986, and commissioning of the repository by the year 2000.

Non-High-Level Waste Treatment, R\&D

Chalk River: concentration of liquid wastes using reverse osmosis.

Solid Waste Treatment, R\&D

Ontario Hydro: development of a waste compactor and a "starved air dualchamber" incinerator. These facilities are now operational in their Radioactive Waste Volume Reduction Facility at Bruce.

Volatile Radionuclides, R\&D

Whiteshell:

- recovery of volatile radionuclides from fuel reprocessing operations

- incorporation of noble gases in solids (e.g., krypton in zeolites). 


\section{FRANCE}

Nuclear Power

Committed: 37 GWe (mainly LWR, also LMFBR, GCR)

Projected: 40 GWe by 1985, 5 GWe/yr increments beyond 1985

Major R\&D: LMFBR (Rapsodie, Phenix, Super Phenix)

\section{Fuel Cycle}

Through the CEA and the state-owned company, COGEMA, France is making extensive efforts to commercialize all steps of the fuel cycle, including its AVM waste vitrification process. Activities include:

- Uranium Enrichment. COGEMA operates gaseous diffusion production plants and has a lead role in the projects for two new multinational enrichment facilities, EURODIF and COREDIF. The CEA has also developed a chemical exchange enrichment process which is to be the basis for a proposed demonstration plant.

- Fuel Fabrication. LWR fuels are produced commercially. The CEA's Cadarche Nuclear Research Centre has responsibility for development and fabrication of MOX fuels for FBRs and future LWR recycle.

- Fuel Reprocessing. COGEMA operates the UP 1 (Marcoule) and UP, (La Hague) reprocessing plants which were constructed to handle natural uranium metal fuels. A 400 tonne/yr head-end for commercial LWR fuels has been added to the La Hague plant, and reprocessing of high-burnup oxide fuels has been started there. Work is also under way on design and construction of a new UP 3 plant at La Hague for commercial LWR fuel reprocessing. UP 3 is to have two parallel lines, each rated at 800 tonne/yr. The first UP 3 line which is to be operational about 1985 is to be used for foreign customers. Marcoule and La Hague each have a small pilot reprocessing plant. The La Hague AT-l plant handles FBR fuels.

HLLW Solidification

Two major processes have been developed at Marcoule.

- PIVER is a pot vitrification process in which HLLW and chemicals are added to the pot and calcined, the temperature is raised and the mixture melted, and the glass is drained into a waste canister. PIVER has been tested on full-level Marcoule waste in the PIVER pilot plant, producing 12 tonnes of glass with a maximum activity of $3000 \mathrm{Ci} / \mathrm{h}$. The PIVER plant is still used for special projects, e.g., process tests with LMFBR HLLW.

- The Marcoule continuous vitrification process uses a rotary calciner coupled to a melting furnace. Product glass drains (batchwise) into the waste canisters (Figure 1). The Marcoule process has been tested in a cold pilot plant with a throughput of $20 \mathrm{~kg} \mathrm{glass} / \mathrm{hr}$. The AVM, a hot 


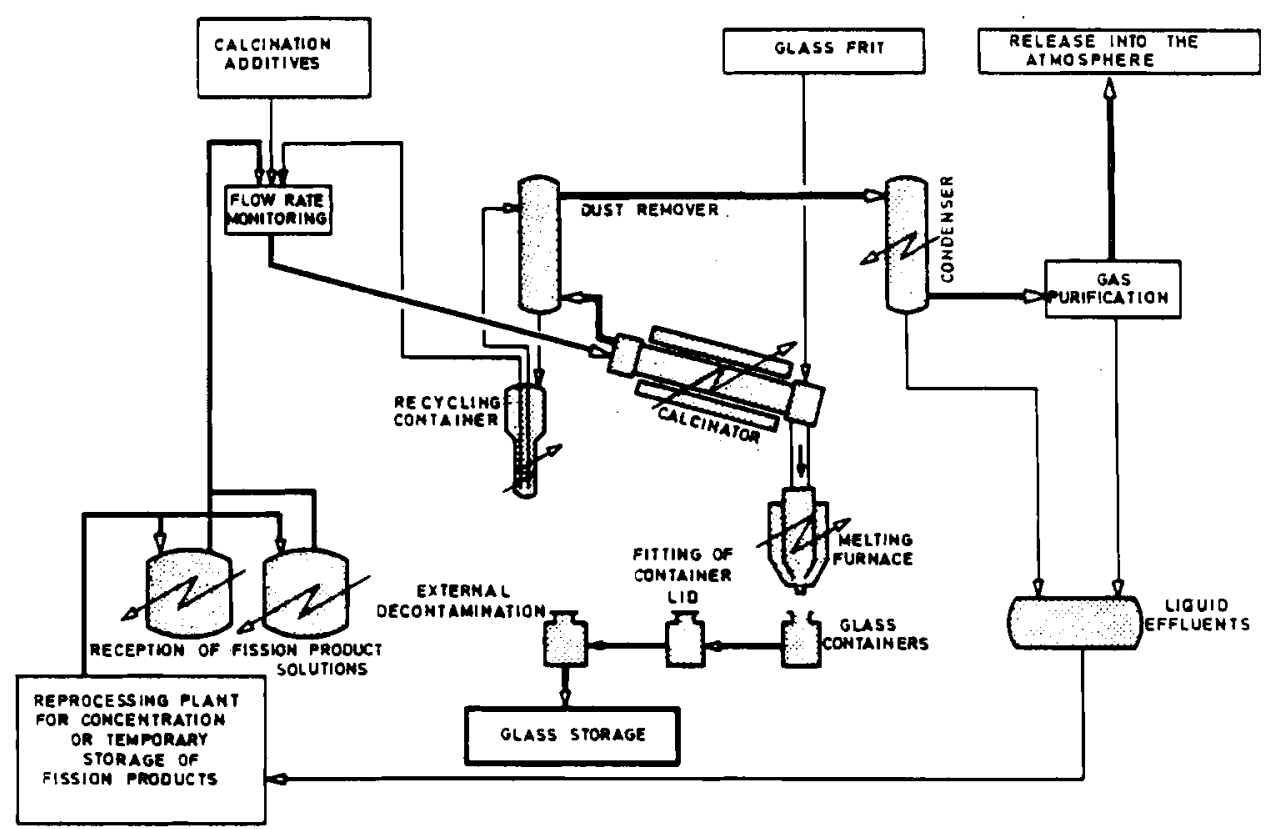

FIGURE 1. Simplified Flowsheet of Vitrification

Plant at Marcoule (AVM) (2)

demonstration plant to be used for solidification of Marcoule HLLW, is undergoing startup tests. Hot operation is scheduled for 1978 with a capacity of $40 \mathrm{l} / \mathrm{hr}$ feed $\left(150 \mathrm{~m}^{3} / \mathrm{yr}\right)$ and $20 \mathrm{~kg} / \mathrm{hr}$ glass. Calciner dimensions are $27 \mathrm{~cm}$ diameter by $3.6 \mathrm{~m}$. Melter dimensions are $35 \mathrm{~cm}$ diameter by $1 \mathrm{~m} \mathrm{high.}$

Since French (COGEMA) contracts to reprocess spent fuel for other nations require return of the HLLW in solid form, France is endeavoring to secure international acceptance of the Marcoule vitrification process and waste glass product. To this end, France has secured Eurochemic agreement to install the Marcoule process at Mol for vitrification of existing Eurochemic high-level wastes.

TRU Waste Treatment, R\&D

Fontenay-aux-Roses: partitioning and transmutation of alpha wastes.

Marcoule:

- vitrification of TRU wastes

- characterization of glasses doped with alpha emitters. (A new hot cell for leach-testing and strength measurements on glasses doped with ${ }^{242} \mathrm{Cm}$ is planned.) 


\section{Waste Isolation}

The planned disposal method for alpha-bearing wastes is emplacement in deep geological formations. For fission products, eitier geologic disposal or longterm storage in engineered facilities is a possible solution. The formations presently being studied for geologic disposal are rock salt and crystalline rocks. The reconnaissance of salt formations in France has indicated the existence of several promising areas. However, present plans are to devote a significantly greater effort to crystalline rocks.

The possibility of disposal in granite has been evaluated for the site of La Hague, and plans are under way for a large program that will evaluate many other crystaliine-rock formations. This program will be partially financed by the Commission of European Communities. The target date for the first pilotplant repository (alpha-bearing waste only) is 1985.

Marcoule has an air-cooled underground facility for interim storage of AVM waste glass. Cadarache is testing "capiliary barrier" techniques for shallow land burial.

Non-HLLW

- Bituminization: R\&D is being conducted at Cadarache (thin-film evaporator dehydration of the waste-bitumen emulsion, twin-screw extruder plant), Marcoule (screw-extruder), and Saclay (commercial turbulent-film-evaporator process).

- Incorporation in Thermo-Setting Resins: Pilot-plant tests are now being performed at Grenoble. Construction of demonstration plant was started in 1977 .

- Incorporation in Concrete: Production operations at Saclay immobilize non-HLLW in concrete.

Cladding Hulls, R\&D

Marcoule: meltdown of zirconium cladding hulls for consolidation and decontamination.

\section{Solid Wastes}

- Cadarache has built a pilot plant (operational in 1977) for crushing solid alpha-contaminated wastes at liquid air temperatures.

- Marcoule operates two incinerators (up to 60 to $70 \mathrm{~kg} / \mathrm{hr}$ feed) for burning solid contaminated wastes.

Volatile Radionuclides, R\&D

Fontenay-aux-Roses: A noble-gas cryogenic separation unit has been built. Tests with this unit are to be followed by pilot-scale tests at Marcoule or La Hague. 


\section{GERMANY, FEDERAL REPUBLIC OF (FRG)}

Nuclear Power

Committed: 28 GWe (mainly LWR; also LMFBR, THTR, PHWR)

Projected: $\quad 30$ GWe by $1985 / 1986$

R\&D: HTGR and LMFBR systems

Uranium Enrichment

The FRG firm CENTEC has partnership with British and Dutch companies in the URENCO consortium, which operates centrifuge enrichment plants at Capenhurst, England and Almelo, Holland. CENTEC also plans to construct a centrifuge plant in FRG.

KfK is working on the development of Becker "nozzle process" technology. FRG and Brazil are cooperating in the construction of a Brazilian pilot plant based on the Becker process.

\section{Fuel Fabrication}

Development and fabrication of MOX fuels for FBRs and recycle to LWRs are handled by ALKEM at Hanau. HTGR fuel fabrication and development (uranium oxides and carbides; thorium oxides) are the responsibility of KFA at Jülich.

\section{Fuel-Cycle: Back-End}

The Federal government, nuclear power producing utilities, and other private enterprises are deeply involved in the back-end of the nuclear fuel cycle. Major effort is going into development of the Nukleares Entsorgungs Zentrum (NEZ), the proposed spent fuel element disposal centre that is to be built at Gorleben. NEZ has been divided into the seven areas of activity shown be 10 .

\begin{tabular}{|c|c|}
\hline Activity & $\begin{array}{l}\text { Target Date } \\
\text { for Operation } \\
\end{array}$ \\
\hline $\begin{array}{l}\text { Fuel reception and storage } \\
\text { Reprocessing }\end{array}$ & $\begin{array}{l}1986-1 \mathrm{st} \\
1990-2 \mathrm{nd} \\
1990\end{array}$ \\
\hline $\begin{array}{l}\text { Uranium storage and } \\
\text { conversion }\end{array}$ & 1990 \\
\hline $\begin{array}{l}\text { Plutonium storage, conver- } \\
\text { sion and Mox fabrication }\end{array}$ & 1990 \\
\hline $\begin{array}{l}\text { Waste management } \\
\text { Waste disposal } \\
\text { Infrastructure }\end{array}$ & $\begin{array}{l}1986-1990 \\
1996 \\
1982\end{array}$ \\
\hline
\end{tabular}

\section{Fuel Reprocessing}

The following R\&D is being done:

- KfK, Karlsruhe: Large-scale, cold testing of process operations and equipment in the "TEKO Hall" facility

- GWK: WAK pilot plant (40 tonne/yr capacity) 
- KFA, Jïluch: JUPITER pilot plant $(2 \mathrm{~kg} / \mathrm{day})$ for reprocessing HTGR fuels; Startup: 1980.

A 1400 tonne/yr reprocessing plant is planned for the NEZ at Gorleben. In the interim, the German utilities plan to have their spent fuels reprocessed by COGEMA at the La Hague plant in France.

\section{HLLW Solidification}

Extensive effort has gone into development of the following solidification processes.

- VERA Process (KfK, Karlsruhe) for Purex-type wastes: For several years, development work was centered on a spray-calciner/metallic melter process which produces a borosilicate glass. These operations were tested extensively in the VERA pilot plant (cold) and in hot-cell runs.

In 1977, work on the spray-calciner/metallic melter process was aropped in favor of calcination and melting in a ceramic melter unit. The HLLW is sprayed or dropped into the melter at melting temperature, and the waste glass produced is drained into waste canisters (Figure 2). The pilot-scale melter has been tested extensively at feed rates up to $30 \mathrm{~h} / \mathrm{hr}$ HLL.W with nonradioactive feed.

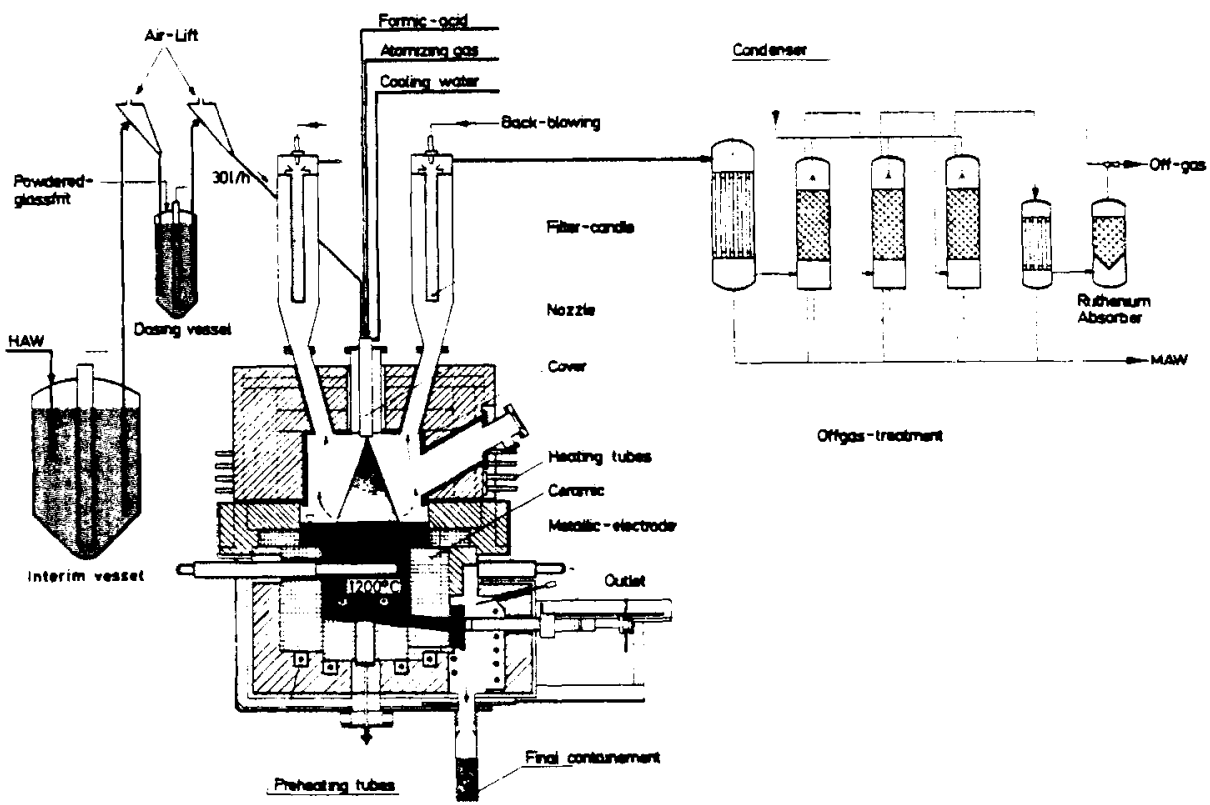

FIGURE 2. Simpitified Flowsheet and Il lustration of Compact Ceramic Unit (VERA) (3) 
Future plans for VERA are uncertain since the French AVM process has been chosen by German authorities as the reference vitrification process in their licensing applications for the WAK vitrification facility and the new fuel cycle center.

- FIPS Process (KFA, Jülich) for thorium-containing HTGR wastes: FIPS uses a drum dryer and rising-level in-pot melting to produce a borosilicate glass. The process has been tested cold and in a hoi-cell facility (l kg/ hrglass). A pilot plant (10 kg/hr glass) is planned.

- PAMELA Process (Gelsenberg A. G., Jülich and Mol, and EUROCHEMiC, Mol): PAMELA involves phosphate glass production in a ceramic melter, drainage of the glass through a bead maker, and incorporation of the beads in a metallic (lead alloy) matrix. The vitrification and bead-making operations (Figure 3) were developed by Gelsenberg in KFA facilities at Jülich. The technology for making the glass-metal matrix was developed by Eurochemic. The process has been tested cold and with Eurochemic HLLW.

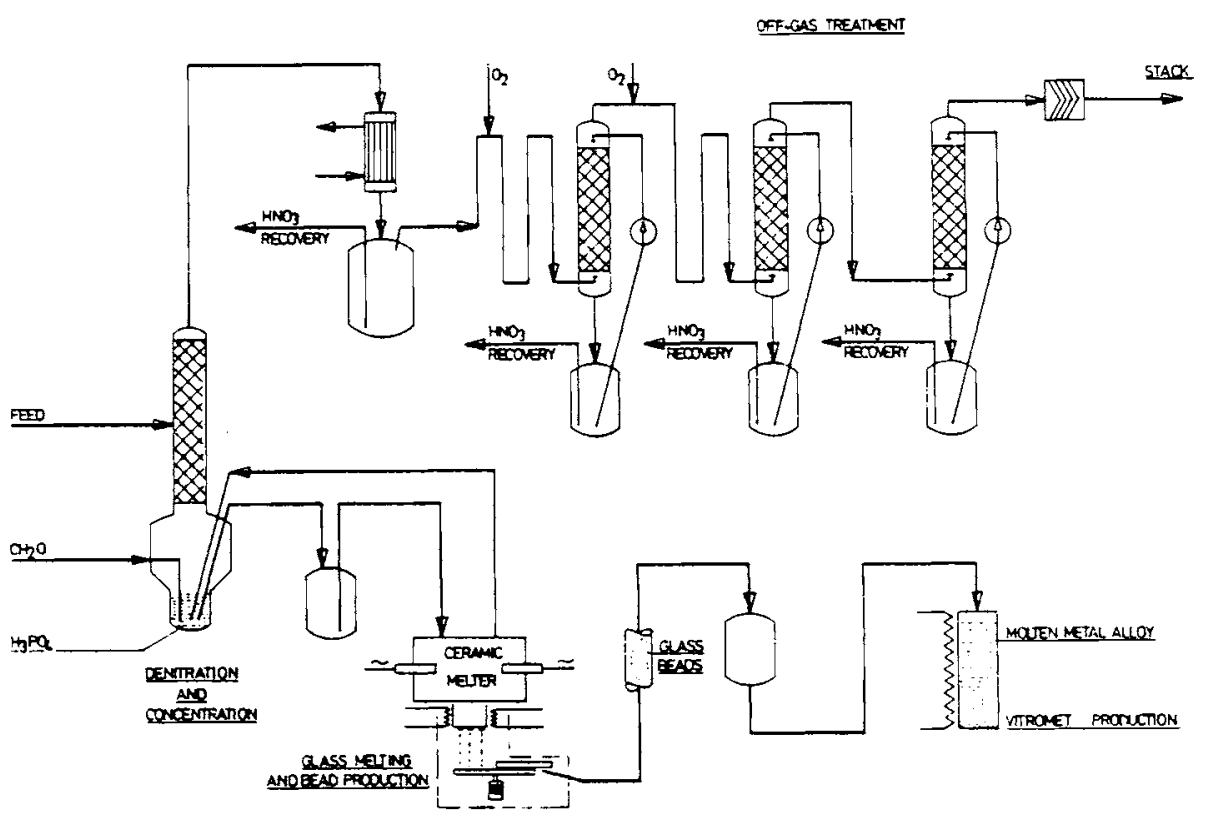

FIGURE 3. Simplified Flowsheet of the PAMELA Process $(2)$

Gelsenberg, with Federal government support, now plans to construct a small PAMELA pilot plant in Eurochemic space at Mol. Startup of the $30-40$ 2/hr HLLW pilot plant is scheduled for 1982-1983. Other projects in progress include:

- a thermite process to produce a ceramic (KfK),

- formation of glass-ceramics by devitrification (KfK and HMI), and 
- fixation in concrete $(K f K)$.

Studies of high-level waste form properties are conducted at $K f K$, KFA, and HMI.

TRU Waste Treatment, R\&D

KfK:

- partitioning of TRU wastes

- characterization of waste glasses containing alpha-emitters

- design of a TRU-waste incinerator.

Waste Isolation

FRG is well advanced in developing a salt-mine geologic repository for radioactive wastes, with the following activities:

- operation of the Asse salt mine as a repository for non-high-level wastes

- evaluation of salt mine storage of solidified high-level wastes and spent fuel elements from the AVR pebble-bed reactor

- evaluation of the Konrad iron mine for waste isolation

- planning for the installation of a waste isolation facility in the salt beds below the proposed national waste management center at Gorleben

- safety assessment.

Non-High-Level Waste Treatment, R\&D

KfK Karlsruhe: development of waste forms that can be pumped into a salt cavern and allowed to solidify in place.

Cladding Hulls, R\&D

$\mathrm{KfK}$ :

- properties of hulls (e.g., heat generation, tritium release)

- immobilization of hulls in concrete.

Solid Wastes, R\&D

KfK: wet oxidation and mechanical compaction studies.

Volatile Radionuclides, R\&D

$K f K$ :

- iodine and tritium control in a separations plant

- recovery and separation of $\mathrm{kr}$ and $\mathrm{xe}$ (cold piiot plant, $50 \mathrm{~m}^{3} / \mathrm{hr}$ capacity, for $85 \mathrm{kr}$ recovery)

- ${ }^{85} \mathrm{kr}$ storage in a metal matrix. 
KFA :

- AKUT process for $I_{2}$, $K r$, Xe removal from plant off-gas

- separation of ${ }^{85} \mathrm{Kr}$ by fractional distillation (KRYOSEP facility for ${ }^{85} \mathrm{Kr}$ removal from JUPITER pilot reprocessing plant).

\section{INDIA}

\section{Nuclear Power}

Committed: 0.4 GWe (LWR); 1.3 GWe (PHWR); LMFBR prototype

Projected: 6 GWe by 1990; 20 GWe by 2000 including $5-7$ GWe in FBRs

R\&D: LMFBR; thorium fuel cycle.

\section{Fuel Cycle}

National objectives are to

- develop nuclear fuel cycle self-sufficiency, with full capacity to meet the country's needs for heavy water, fuel reprocessing and waste immobilization

- develop a ${ }^{233} \mathrm{U}-\mathrm{Th}$ nuclear power system.

The high population density and limited transport facilities of India have led to a national policy of setting up small-capacity fuel reprocessing/waste solidification/interim waste storage complexes at several locations, rather than to establish a centralized, large-capacity plant.

\section{Fuel Reprocessing}

Two plants are operable:

- The Trombay pilot plant, 60 tonne/yr, is designed to handle either metal or mixed oxide fuels.

- The Tarapur plant is designed to handle 100 tonne/yr of oxide fuels

- A third plant at kalpakkam is planned. It is to be designed for CANDU and thorium FBR fuels from the Madras power station.

\section{HLLW Solidification}

A waste immobilization plant is under construction at Tarapur, scheduled for startup in 1979-1980. It is based on a semicontinuous pot process developed at Trombay. The HLLW feed is preconcentrated, then calcined in the calcinermelter pot. When the pot is $75 \%$ full of calcine, the waste is melted and drained into a waste canister.

\section{TRU Waste Treatment, R\&D}

BARC, Trombay:

- partitioning of TRU wastes

- conversion of TRU wastes into insoluble alumino-sijicates by a hydrothermal process. 


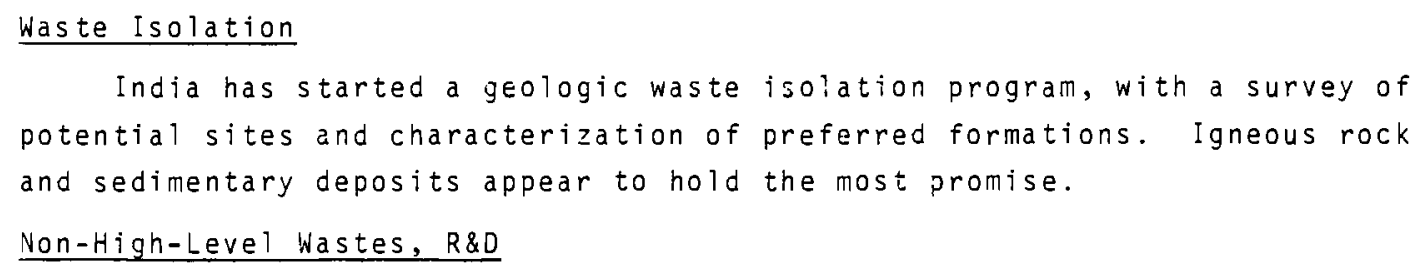

Cladding Hulls

Tarapur is developing techniques for interim storage of Zircaloy cladding hulls in cylindrical tile holes in the ground.

\section{$\underline{\text { IRAN }}$}

Nuclear Power

Committed: 4 GWe (LWR)

Projected: 22 GWe by 1992; 34 GWe by the year 2000

Vote: Iran depends on UK for technical assistance and R\&D.

Fuel cycle

Iran has a share of the proposed multinational Eurodif and Coredif gaseous diffusion plants and plans to develop complete fuel cycle capability.

\section{Waste Management}

UKAEA has been employed by Iran to evaluate the problems associated with the storage and management of spent fuel and radioactive waste from Iran's nuclear power plants. Options considered for spent fuel handing will include extended pool storage after recanning, reprocessing either in Iran or abroad, and vitrification and geologic isolation of high-level wastes. Second-stage spent fuel facilities are required by 1984, when it will be necessary to remove fuel elements from the storage pond at Bushehr.

In response to an Iranian invitation, Austria and Iran are negotiating on a proposal to store Austria's nuclear wastes in the Iranian desert.

\section{ITALY}

Nuclear Power

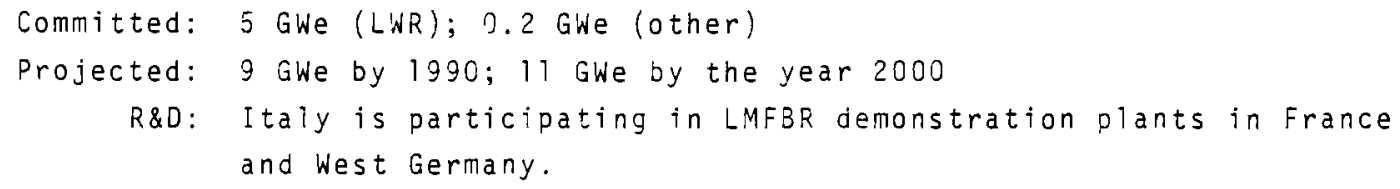




\section{Fuel Cycle}

Italy hopes to become independent of other countries for nuclear fuel supplies by developing a strong breeder reactor industry. Activities include enrichment (participation in Eurodif), fabrication (U and recycled U-Th-Pu fuels), and reprocessing.

\section{Fuel Reprocessing}

Italy has two operational reprocessing pilot plants:

- The EUREX plant at Saluggia in northern italy is designed to reprocess $30 \mathrm{~kg} /$ day of MTR fuels. It has been modified to handle oxide fuels.

- The ITREC pilot plant at the Trisaja Center near Rotondello in Southern Italy is designed for $233 \mathrm{U}-T h$ and U-Pu fuels with a $15 \mathrm{~kg} /$ day capacity.

A new 1200 tonne/yr reprocessing plant is planned as part of a spent fuel storage, reprocessing and waste treatment center. Startup is scheduled for the late 1990s.

\section{HLLW Solidification}

ESTER, developed at CSN-Casaccia, is a multistage pot calcination vitrification process that may produce either a phosphate or a borosilicate giass. It has been tested in hot-cell runs at Ispra. The French Marcoule vitrification process is under consideration for installation at the proposed reprocessing and waste treatment center.

TRU Waste Treatment, R\&D

CSN-Casaccia:

- actinide partitioning

- transmutation for TRU disposal.

AGIP Nucleare:

- combination of TRU wastes in motten salts.

Waste Isolation

Italy is studying geologic waste isolation. Present plans are to evaluate piastic argillaceous sediments in the Trisaia area as possible sites, with coring studies, in situ tests, engineering work, and safety analysis. A pilot plant repository is planned, to be operating by the mid-1980s.

Non-HLLW Treatment, R\&D

CSN-Casaccia: use of polymer-impregnated cement for nuclear wastes.

Solid Wastes, R\&D

AGIP Nucleare: combustion of solid wastes in molten salts. 
Nuclear Power

Committed: 18 GWe (LWR); 0.3 GWe (LMFBR); 0.3 GWe (other)

Projected: 40 GWe by $1985 ; 90$ GWe by 1990

R\&D: FBR technology; fusion

Fuel cycle

Japan is endeavoring to become independent of other nations in the nuclear fuel cycle field. The Japanese program is directed toward these objectives:

- direct participation in overseas uranium mining projects

- development of plutonium recycle to conserve uranium

- development of uranium enrichment capability (A gas centrifuge pilot plant is planned. In the interim, Japan will buy enriched uranium from outside suppliers.)

- operation of the Tokai fuel reprocessing plant (210 tonne/yr) and construction of one or two 1500 tonne/yr reprocessing plants, the first in the late 1980s. (Japan will rely on reprocessing by English and French plants until their own plants can handle the load.)

Japan relies on private industry for fabrication of LwiR uranium fuels ana on PNC for development and fabrication of plutonium fuels.

\section{HLLW Solidification, R\&D}

PNC: Fluidized bed calcination of high-sodium HLLW, calcine converted to glass or ceramic

JAERI-Tokai: rotary kiln calcination and vitrification of waste-ioaded zeolite ion exchangers

Governiment Research Institute, Osaka: sintering or hot-pressing (with Pyrex glass and Cu powder additives) of calcined wastes; devitrification of waste glasses; waste solidification facility to be built for startup in 1981; a demonstration waste solidification facility for PNC wastes to start up in 1986.

TRU Waste Treatment, R\&D

JAERI-Tokai: evaluate TRU partitioning scheme.

PNC: test incinerator for TRU-contaminated combustible solids.

Waste Isolation

The Science and Technology Agency is sponsoring an extensive program to develop geologic disposal sites in japan for high-level wastes. JAERI is to conduct the safety studies. Under subcontract with UAERI, Mitsubishi Metals 
Corporation is making a survey of Japan for potential sites. Its preliminary report, issued in 1977, identifies geological bodies of granite and zeolite rock as attractive possibilities, and suggests further consideration of limestone, diatomite and shale formations. Preliminary concepts of geological disposal systems have also been developed.

Various agencies are involved in studies of deep-sea disposal of low-level wastes. These studies inciude tests of the mechanical behavior of packages under hydrostatic pressures, and leaching.

Non-High-Level Waste Treatment, R\&D JAERI :

- instaliation of a batchwise bituminization unit at OARAI

- use of polyethylene to immobilize spent ion exchange resins

- use of plastic-impregnated concrete containers for waste disposal.

Volatile Radionuclides

Under PNC sponsorship, several groups are studying the recovery and storage of ${ }^{85} \mathrm{Kr}$, with emphasis on cryogenic distiliation, selective membranes for krypton recovery from cover gases, cryogenic absorption-desorption, and thermal diffusion for krypton-argon separation.

\section{SPAIN}

\section{Nuclear Power}

Committed: 16 GWe (LWR); 0.5 Giwe (GCR) by 1987

Projected: Plans beyond 1987 are uncertain.

Fuel Cycle

Spain is working for extensive fuel cycle capability:

- Uranium Enrichment: Spain has partnership in EURODIf.

- Fuel Fabrication: Plans to develop Mox fuel fabrication capability are reported.

- Fuel Reprocessing: Between 1967 and 1971, Spain operated a 5mall pilot plant in Madrid to reprocess spent MTR fuels. A new laboratory-scale reprocessing facility $(2000 \mathrm{~kg} / \mathrm{yr})$ is being designed.

\section{HLLW Solidification}

Laboratory-scale studies of several techniques to solidify wastes from MTR fuel reprocessing (denitration, calcination, sintering, and vitrification) have been conducted at the Juan Vigon Nuclear Energy Centre, Madrid.

\section{Waste Isolation}

Spain is presently disposing of low-and intermediace-level wastes in abandoned uranium mines located in the sierra Morena. The country is also 
being surveyed for other potential sites. Promising formations include crystalline rocks, shales, rock salt, tertiary clays and gypsum. A pilot plant repository, to start up in the late 1980s, is planned.

Non-High-Level Waste Treatment, R\&D

- volume reduction and chemical decontamination of non-high-level wastes

- incorporation of solids in cement.

\section{SWEDEN}

\section{Nuclear Power}

Committed: 9.4 GWe (LWR) by 1985

Projected: The Swedish utilities have planned on major nuclear power increases, but the present political climate in sweden is such that no projections can be made.

\section{Fuel Cycle}

The Swedish Government Committee on Radioactive Waste (AKA Committee) recommended in 1976 that Sweden develop reprocessing and waste management capability. Subsequently, a law was passed requiring that safe disposal of nuclear wastes be assured before any new reactors be loaded with fuel and commence operation. In response, the Swedish utilities have sponsored a crash effort to develop a plan for geologic disposal of either spent fuel elements or solidified high-level waste, and have contracted with COGEMA (France) for reprocessing of Swedish spent fuel at La Hague.

\section{HLLW Solidification}

Swedish technical groups are conducting the following R\&D programs:

- ASEA-Atom is developing hot isostatic pressing techniques for encapsulating spent fuels, preparing high-density waste ceramics from mixtures of waste calcine with materials such as $\mathrm{Al}_{2} \mathrm{O}_{3}$, and converting fission-productloaded, inorganic-ion-exchange resins into dense ceramic bodies.

- The Royal Institute of Technology in Stockholm is working on absorption of fission products from HLLW onto titanate ion exchange resins, which can then be converted to dense ceramic bodies.

TRU Wastes, R\&D

Chalmers University: TRU partitioning.

\section{waste Isolation}

The Swedish Nuclear Fuel Safety Project (KBS), established in early 1977 by four nuclear power utilities, has issued the draft of a report recommending the following HLLW management scheme: 
- interim storage of spent fuels in a central storage facility

- reprocessing at La Hague in France and return of vitrified wastes to Sweden

- thirty-year storage in air, in an underground rock formation

- application of a lead plus titanium overpack and empiacement in granite formations $500 \mathrm{~m}$ underground.

Research and development is under way in the following areas:

- design of underground spent-fuel storage pools

- preparation to commission a pilot waste repository

- supporting studies (field tests in the Stripa mine, design and testing of equipment, ground water movement measurements, and safety assessment).

\section{SWITZERLAND}

Nuclear Power

Committed: 5.8 GWe (LWR) by 1982

Projected: another 3 GWe

\section{Fuel cycle}

Switzerland currently depends on other countries for fuel cycle services and has a contract with COGEMA for reprocessing through 1989. For the future, the utilities plan to build central facilities for interim spent fuel storage and hope to participate with other countries in the construction of new reprocessing plants and related receiving ponds.

Waste Disposal, R\&D

EIR, Würenlingen: Evaluation of geologic disposal in rock formations in the Swiss Alps and in anhydrite formations elsewhere.

\section{UNITED KINGDOM}

Nuclear Power

Committed: 11 GWe (mainly GCR; 250 MWe LMFBR)

Projected: Up to 100 GWe (total) by the year 2000; 33 GWe (LMFBR) by 2010

R\&D: LMFBR, with emphasis on complete FBR fuel cycle.

Fuel Cycle

The United Kingdom has extensive nuclear fuel cycle capability and programs.

- Uranium Enrichment: UK operates gaseous diffusion plants at Capenhurst and has partnership in URENCO, with a gas centrifuge plant at capenhurst. 
- Fuel Fabrication: Extensive plutonium fuel fabrication R\&D is conducted at windscale, and work on Mox fuel recycle for FBRs is conducted at Dounreay.

- Fuel Reprocessing: BNFL operates a 1500-2500 tonne/yr reprocessing plant at Windscale, designed for Magnox-clad uranium metal fuels. The Windscale plant has been equipped with an oxide fuel headend rated at 400 tonne/yr. BNFL also plans to build a 1200 tonne/yr plant (THORP) for commercial LWR fuels and intends to offer reprocessing service to other nations.

The Dounreay site has a 10 tonne/yr reprocessing pilot plant which was recently decontaminated and equipped to handle Mox spent fuel from the prototype LMFBR at Dounreay, the PFR.

\section{HLLW Solidification}

The UK has concentrated on developing the FINGAL/HARVEST process, which produces a borosilicate waste glass by the rising-level process (Figure 4 ). HLLW and glass formers are slowly added to a pot maintained at about $1050^{\circ} \mathrm{C}$. Evaporation, calcination and vitrification occur simultaneously. Studies have been conducted at Harwell in:

- the FINGAL pilot plant, which was shut down in 1966 after process demonstration with actual HLLW from windscale

- the Harwell nonradioactive, full-scale pilot plant which started operation in 1975; in runs through 1976, the giass batch size was maintained at $240 \mathrm{~kg}$.

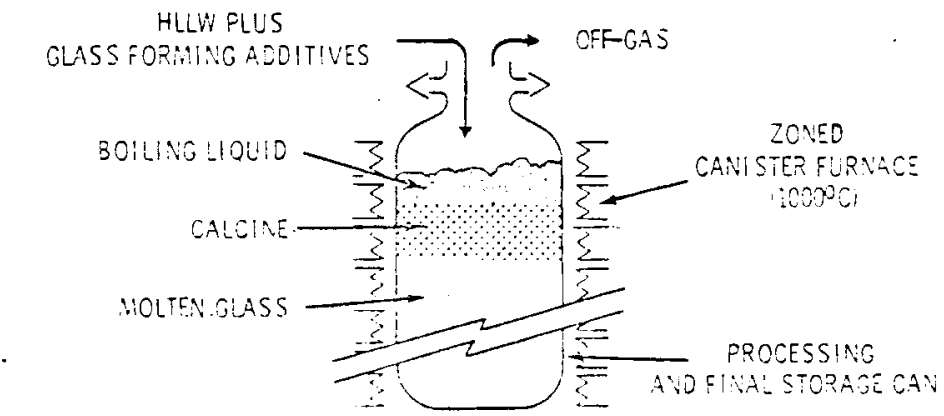

FIGURE 4. Simplified Flowsheet of FINGAL Process (4)

These major facilities are planned for windscale:

- an active pilot plant at Windscale for making Kg-scale glass blocks from Windscale HLLW (capacity = $12 / \mathrm{hr}$ HLLW; startup in 1979) 
- a hot cell facility for glass examination (startup in 1978)

- a full-scale prototype of the first production-scale demonstration plant, for nonradioactive testing (startup in 1980)

- an industrial-scale demonstration plant (startup in 1986; full-level operation with windscale wastes in 1988); this plant is to use cylindrical vessels up to $61 \mathrm{~cm}$ in diameter by $2.74 \mathrm{~m}$ high which will contain 1.26 tonne of glass

- a full-scale production plant (startup in 1990).

With national emphasis on developing technology for the complete LMFBR fuel cycle, the UKAEA has started a project to build a waste vitrification piant at Dounreay. Criteria for the plant are that it have a $30 \mathrm{l} / \mathrm{hr}$ feed capacity and be operational by the late 1980s. UKAEA and BNFL personnel are evaluating a number of vitrification processes for this application.

TRU Waste Handi ing, R\&D

Harwe 11:

- properties of vitrified TRU wastes

- transmutation of actinides.

Waste Isolation

The Institute of Geological Sciences (IGS) has recently completed a desk survey of the UK to identify where rock formations occur that might meet the criteria for geologic disposal. In the UK it seems likely that there are two options: clay formations and crystalline rocks. This study is to be followed by a 5-yr program aimed at identifying areas for more detailed geological study (structural, hydrogeological, seismic, etc.) so that sites can be selected for trial boreholes. Supporting studies of the effect of heat on selected rock formations, compatibility of containers and rocks, development of any new borehole logging technique needed, and methods for measuring the "age" of groundwater would be included.

Non-High-Level Wastes, R\&D

Harwell: cleanup and disposat of used solvent.

Cladding Hulls

AERE/Harwel1: properties, compaction and encapsulation of stainless steel and Zircaloy cladding hulls.

\section{Solid Waste Treatment}

AERE/Harwel1:

- low-temperature pyrolysis

- acid-digestion 


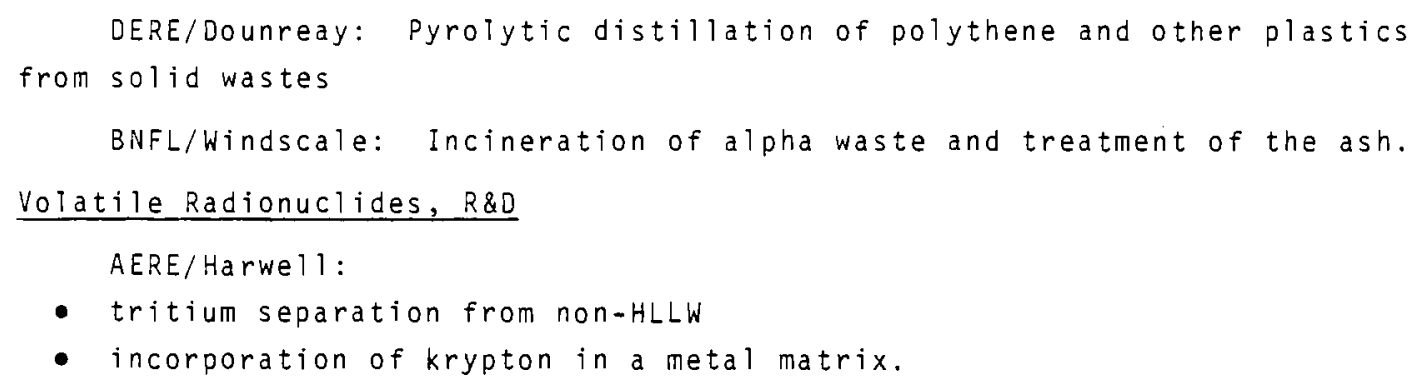

$\underline{\text { USSR }}$

Nuclear Power

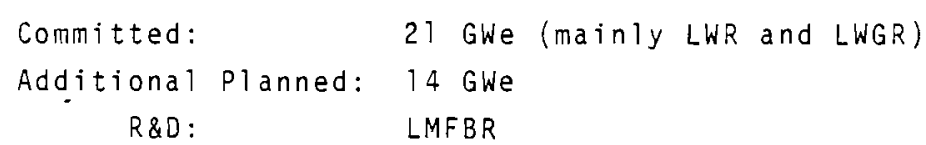

Fuel Cycle

The Soviet Union does not have a commercial-scale spent fuei reprocessing plant on line (May 1977), but is reportedly building one with a 5 tonne/day capacity to be operational by about 1980. A vitrification plant, to be located with the reprocessing plant, is also projected. A small experimental (several $\mathrm{kg} / \mathrm{day}$ ) reprocessing facility is operational at the klopin Radium Institute.

HLLW Solidification

The Soviet Union has reported on development of three waste solidification processes.

- Single-stage Phosphate Glass Process: Evaporation, calcination and vitrification are carried out in a refractory-lined metal box divided vertically into two zones (Figure 5). The waste (up to $100 \mathrm{l} / \mathrm{hr}$ ) and glass formers are added to the top of the larger zone; the molten glass is poured into a $200-2$ container from the smaller zone. The nonradioactive unit has been operated for about $3 \mathrm{yr}$ and has produced over 300 tonnes of glass.

- Two-stage Fluidized Bed Phosphate Glass Process: This process uses a fluidized bed calciner ( $1.4 \mathrm{~m}$ in diameter by $4.6 \mathrm{~m}$ high) which feeds to an induction-heated concrete refractory melter-canister. capacity: $20 \mathrm{~kg}$ glass/hr; the containers hold $160-180 \mathrm{~kg} g l a s s$.

- Chemo-thermal process: In this technique waste calcine is reacted with appropriate chemicals in an exothermic process which produces basalt-like materials.

Waste Isolation

Although studies of geologic isolation for HLW have been made, the Russians seem to be emphasizing surface storage for solidified HLW. Guiding principles are that the repository should adjoin the vitrification buiding, be abcre the 


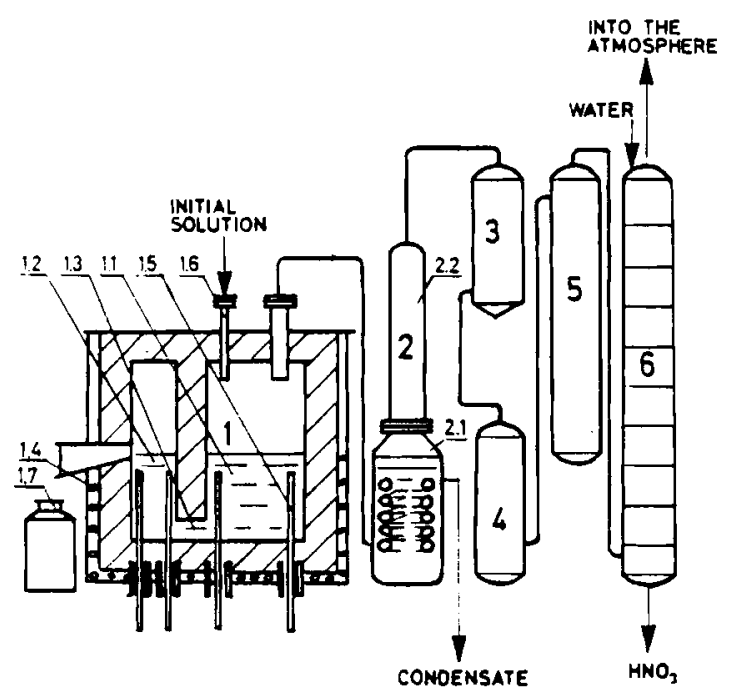

FIGURE 5. Simplified Flowsheet and an Illustration of Electric Furnace for Russian Single-stage Process( 3 )

water table, and be converted section by section to a "tomb" as the waste ages and heat generation decreases. Non-high-level wastes have been pumped through boreholes into quartz, sandstone and clay strata at a depth of $1400-1500 \mathrm{~m}$ at a site near Dimitrovgrad.

\section{INTERNATIONAL ATOMIC ENERGY AGENCY (IAEA)}

A major IAEA program is in the field of nuclear safety and environmental protection. Its purpose is to ensure the safe operation of nuclear installations and the protection of man and his environment from the harmful effects of nuclear radiation and radioactive or nonradioactive releases from nuclear installations.

In the waste management area, the IAEA provides a multinational focus for investigation and development in problem areas which ultimately may be handled satisfactorily only through international soiutions.

The IAEA's waste management activities include:

- development of mutually agreed-upon safety standards and criteria for the management and disposal of radioactive waste arising from all stages of the nuclear fuel cycle

- promotion of information exchanges in the radioactive waste management area via international conferences and symposia, technical committees and advisory groups for seiected areas of technology, and specialized training courses and seminars

- coordination of research programs in specific technical areas 
- issuance of publications in the field of waste management including the annual "Waste Management Research Abstracts."

Limited IAEA funds (generally $\$ 150,000-\$ 200,000$ annually) are provided for research and development in selected areas of radioactive waste management and environmental assessment, usually for coordinated research programs involving participation by member states.

\section{COMMISSION OF THE EUROPEAN COMMUNITIES (CEC)}

CEC sponsors and funds nuclear R\&D at the research establishments of the CEC (formerly Euratom) Joint Research Centre and in the laboratories of the Member States. Funds for the national laboratories of the Member States are generally provided on a matching basis. In 1975 , CEC budgeted $\$ 26 M$ for a 5 -yr radioactive waste management program, with about $\$ 16 \mathrm{M}$ devoted to geologic disposal. Sponsored activities reported in the First Annual Report, for CY-1976, are listed in table 7 .

A summary for JRC-Ispra is provided below.

Member States of CEC are:

$\begin{array}{ll}\text { Belgium } & \text { Italy } \\ \text { Denmark } & \text { Luxembourg } \\ \text { France } & \text { The Netherlands } \\ \text { West Germany (FRG) } & \text { United Kingdom } \\ \text { Ireland } & \end{array}$

CEC: Joint Research Centre (Ispra)

HLLW Solidification

Ispra conducted hot-cell tests of the Italian ESTER waste vitrification process.

TRU Waste Treatment, R\&D

- TRU partitioning

- long-term stability of bituminized alpha wastes. Waste Isolation

The Ispra laboratory is participating in CEC studies of geologic waste isolation. Activities are directed toward the evaluation of long-term hazards of waste disposal and include:

- hazard analysis

- studies of long-term stability of conditioned wastes

- measurements of the interactions of actinides with the environment

- development of instruments to monitor the actinide content of solid wastes. 
TABLE 7. Commission of the European Communities (CEC)

Activity

i. Treatment of Low- and Medium-Level Waste

1.1 Mobile pilot plants for resin imbedding of reactor waste

1.2 Stationary resin imbedding with the CEA technique

2. Decontamination and Decomissioning of Irradiated Fuel Elenent Cladding

2.1 Incorporation in low-melting alloys

2.2 Incorporation in concrete

2.3 Decontamination and conditioning in glass

2.4 Characteristics of the radioactivity in different cladding wastes

3. Incineration of Plutonium-Contaminated Wastes

3.1 High temperature incineration

3.2 Acid digestion process

3.3 Incineration in molten salts

4. Properties of Substances Suitable for Immobilizing High-Level waste

5. Engineered Storage for Solidified High-Level Waste

6. Long Tern Storage and Disposal of Solidified High-Level and/or Alpha-Active Waste in Geological Formations

6.1 Catalog of geological formations suitable for the disposal of radioactive waste

6.2 Storage in salt dome

6.3 Storage in crystalline formations I

6.4 Storage in crystalline formations II

5.5 Storage in clay formations

7. Storage of Gaseous wastes

8. Separation and Transmutation of Actinides

Objective/scope
Develop and operate a mobile pilot plant
to immobilize non-high-level reactor
plant wastes.
CEC participation in polyester resin
imbedding plant at Chooz.
Develop a method to press-compact clad-
ding hulls and imbed them in an alloy.
Develop a process and build a pilot plant
for compacting hults (by rolling) and in-
corporating in concrete.
Develop a process and design a plant for
incorporating fuel hulis in a glass
matrix.
Identify the nature, location and
activity levels of the radioactive con-
ponents in typical irradiated fuel
claddings.

claddings.

Develop incineration techniques for Pucontaminated wastes; build and operate small pilot plant $(10 \mathrm{~kg} / \mathrm{hr}$ ); adapt FL 60 plant to Pu use and operate it.

Develop, test and optimize a pilot plant for wet oxidation of Pu-contaninated solid wastes. Develop a molten salt process for de-
stroying combustibles and dissolving pu stroying combustibles and dissolving Pu compounds. Build

Establish a joint basis for evaluating high-level waste forms by characterizahigh-level waste forms by characterization of similar samples of five differ-
ent types of solidified waste in each ent types of solidified
country's laboratories.

Evaluate three storage concepts: watercooled pond, air-cooled storage, mixed system; water-cooled storage initially, then transfer to air-cooled storage.

Provide catalog of potential waste isolation sites.

Develop and evaluate technology $\mathrm{fcr}$ storage of HLLiw glass blocks in salt cavern. Prepare for storage tasts at Asse.

Select a site in France; study radionuclide migration and geochemical barriers. Identify potential sites; study waste form-host rock compatibility; define engineering requirements fer a demonstration; evaluate ground water problems.

Place in service an experimental under ground cavity in a clay formation at Mo ?

$\begin{array}{ll}11 / 76-12 / 79 & \begin{array}{l}\text { Belgium } \\ \text { (SCK/CEN) }\end{array}\end{array}$

$11 / 76-12 / 79 \quad$ FRG

3/77-4/79 France

$11 / 76-12 / 79$ (UKAEA)

Belgium (SCK/CEY)

FRG (NUKEM)

Italy Nucleare)

10/76-12/79 UK (UKAEA)

FRG (HMI)

Fra (HMI)

Belgium

(Beigonucléaire) FRG (NUKEM) Italy (AGIP

Nucleare)

977

Belgium

Denmark

France

FRG

Italy

Netherlands

UK

$-1984 \quad F R G$

(Karlsruhe)

1976-7] France

(CEA)

(UKAEA)

Beigium

Review Member States' programs for stor ing radioactive krypton, tritium and iodine.

Jeveloo a program for dossigle CEC funding $1976-1977$ to 2000 .
UKAEA 
OECD NUCLEAR ENERGY AGENCY (NEA)

The NEA is a specialized agency of the CECD, set up to promote international cooperation among the OECD countries for the development and application of nuclear power for peaceful purposes through international research and development projects and exchange of scientific and technical experience and information.

In 1975, at the request of the OECD, and building upon previous efforts of the IEA Working Group on Radioactive Waste Management, the NEA established a Radioactive Waste Management Committee (RWMC). Its purpose is to initiate, encourage and coordinate cooperative R\&D activities in the field of radioactive waste management, particularly within NEA member states. RWMC has held a series of meetings and established a number of permanent and ad hoc committees and study groups to deal with specific technical areas.

Current NEA waste management activities are focused on the definition of cooperative programs to develop geologic waste isolation technology.

Member States are:

$\begin{array}{lll}\text { Australia } & \text { Iceland } & \text { Portugal } \\ \text { Austria } & \text { Ireland } & \text { Spain } \\ \text { Belgium } & \text { Italy } & \text { Sweden } \\ \text { Canada } & \text { Japan } & \text { Switzerland } \\ \text { Denmark } & \text { Luxembourg } & \text { Turkey } \\ \text { Finland } & \text { The Netherlands } & \text { United Kingdom } \\ \text { France } & \text { New Zealand* } & \text { United States } \\ \text { Germany, Federal Republic of } & \text { Norway } & \\ \text { Greece } & & \\ \text { * Special Status } & & \end{array}$

\section{Eurochemic}

\section{Fuel Reprocessing}

The Eurochemic Company, sponsored by a number of OECD/NEA countries, * operated the 60 tonne/yr Eurochemic fuel reprocessing plant at Mol from 19681974, and is presentiy negotiating with Belgium for turnover of the plant to a Belgian company for modernization and future operation. Decontamination of the plant by Eurochemic is nearly complete.

* Member States: Austria, Belgium, Denmark, France, FRG, Italy, Luxembourg, Netherlands, Norway, Portugal, Spain, Sweden, Switzerland, Turkey. 


\section{HLLW Solidification}

Eurochemic's spent fuel reprocessing operations produced $873 \mathrm{~m}^{3}$ of highlevel liquid waste, which is stored in acid form. There are two types of HLLW: $67 \mathrm{~m}^{3}$ of Low Enriched Waste Concentrate (LEWC), which are typical Purex wastes from reprocessing LWR fuels; and $806 \mathrm{~m}^{3}$ of High Enriched Waste concentrate (HEWC), high-aluminum wastes from reprocessing MTR fuels. Eurochemic is obligated to convert these wastes to solid forms suitable for interim storage.

To assure that waste solidification technology would be available, Eurochemic has worked on two processes:

- LOTES: This process solidifies waste at low temperatures in a stirred-bed calciner. The phosphate granules produced can be consolidated by melting or can be incorporated in a metal matrix. As of January 1978 process tests were under way in a new, all-steel test unit rated at $10 \mathrm{l} / \mathrm{hr}$ feed rate.

- A Technique for Embedding Waste Particles or Glass Beads in a Low-Melting Alloy: This technique has been demonstrated with LOTES product and with glass beads produced by the German PAMELA process (see the FRG summary, p. 22 ).

In December 1977 the Eurochemic Board decided to use the French AvM (Marcoule) vitrification process (see the Summary for France, $p$. 19) for solidification of the Eurochemic HLLW. The Board also agreed to permit West Germany to build a pilot-scale PAMELA facility on Eurochemic property, and to make available some Eurochemic HLLW for demonstration purposes.

Current plans are to transfer the Eurochemic waste handiing facilities to Belgium after the Eurochemic waste is solidified--probably by June 1982.

Non-High-Level Waste Treatment

- Bituminization: Eurochemic has recently placed in service a continuous, screw extruder-evaporator, "EUROBITUM, "for bituminizing decladding and other intermediate-level wastes. Eurobitum capacity is $650 \mathrm{~m}^{3} / \mathrm{yr}$.

- Spent Solvent Treatment: Eurochemic is constructing the "Eurowatt" solvent treatment plant $\left(1 \mathrm{~m}^{3} / \mathrm{day}\right)$ for conversion of used Purex soivent to forms suitable for disposal.

Cladding Hulls

Eurochemic has deveioped a process for encapsulating fuel end pieces in a $\mathrm{SiO}_{2}$-plastic matrix, underwater.

Solid Wastes, R\&D

R\&D includes studies of acid digestion, pyrolysis and molten-salt combustion for combustible alpha wastes. 
CMEA is the counterpart of OECD for the countries with centrally controlled economies. The organization has a standing commission concerned with the use of atomic energy for peaceful purposes that holds periodic conferences and meetings of national specialists on radioactive waste management technology.

In 1971, CMEA set up a coordinating scientific and technical council concerned with radioactive waste management. The council meets semiannualiy and has given high priority to the development of safe disposal methods for radioactive wastes.

Member states are:

$\begin{array}{ll}\text { Bulgaria } & \text { Mongolia } \\ \text { Cuba } & \text { Poland } \\ \text { Czechoslovakia } & \text { Rumania } \\ \text { East Germany } & \text { USSR } \\ \text { Hungary } & \text { Yugosiavia* }\end{array}$

* Special Status 


\section{REFERENCES}

1. Nuclear News, 21 (3), Mid-February 1978.

2. D. W. Clelland, A. D. W. Corbet, R. Bonniaud, E. Detilleux, and H. Krause, "A Review of European High-Level-Waste-Solidification Technology," Proceedings of the U.S.-ERDA Symposium on the Management of wastes from the LWR Fuel Cycle, Denver, Colorado, July 11-16, 1976, CONF-76-0701, pp. 137-165.

3. IAEA, "Techniques for the Solidification of High-Level wastes," Technical Reports Series No. 176 , Vienna, 1977.

4. Alternatives for Managing Wastes from Reactors and Post-Fission Operations in the LWR Fuel Cycle, ERDA-76-43, Energy Research and Development Administration, Washington, DC, May 1976. 


\section{DISTRIBUTION}

No. of

Copies

\section{UNITED STATES}

A. A. Churm

DOE Chicago Patent Group

9800 South Cass Avenue

Argonne, IL 60439

Deputy Director for Fuels and Materials

NRC Directorate of Licensing

for Fuels and Materials

4915 St. Elmo Avenue

Bethesda, MD 20014

W. P. Bishop

Assistant Director for Radioactive Waste Management Branch

NRC Division of Materials and Fuel Cycle Facility Licensing Washington, DC 20555

W. G. Belter

DOE Division of Biomedical and Environmental Research

Earth Sciences Branch

Washington, DC 20545

W. A. Brobst

DOE Division of Environmental

Control Technology

Washington, DC 20545

W. E. Mott

DOE Division of Environmental

Control Technology

washington, DC 20545

G. W. Cunningham/J. A. Leary

DOE, Administrator for Nuclear Energy Programs

Washington, DC 20545

R. B. Chitwood

DOE Division of Nuclear Power

Develooment

Washington, DC 20545

C. R. Cooley

DOE Division of Waste Management

Washington, DC 20545

C. H. George

DOE Division of Waste Management

Washington, DC 20545

C. A. Heath

DOE Division of Waste Management

Washington, DC 20545
No. of

Copies

G. Derte1

DOE Division of Waste Management

Washington, DC 20545

A. F. Perge

DOE Division of Waste Management Washington, DC 20545

J. M. Taub

DOE Division of Waste Management

Washington, DC 20545

D. L. Vieth

DOE Division of Waste Management Washington, DC 20545

R. D. Walton

DOE Division of Waste Management Washington, DC 20545

R. D. Thorne/P. Afanasenko

Energy Technology

U.S. Department of Energy

Washington, DC 20545

R. W. Ramsey

ECT Division

U.S. Department of Energy

Washington, DC 20545

H. Jaffe

AIA Division

Department of Energy

washington, DC 20545

M. D. McDonough

AIA Division

Department of Energy

Washington, DC 20545

2 W. P. Bishop

Nuclear Regulatory Commission

washington, DC 20555

2 Dave Smith

Technology Assessment Division Environmental Protection Agency Wasnington, DC 20460

Delacroix Davis, Jr., Manager WIPP Project office

P0 Box 6400

Albuquerque, NM 87115

R. H. Baver, Manager

Department of Energy

Chicago Operations office

9800 South Cass Avenue

Arganne, IL 60439 
C. E. Williams, Manager Idaho Operations Office Department of Energy 550 2nd St.

Idaho Falls, ID 83401

K. R. Braziel, Manager Los Alamos Area Office Department of Energy LOS Alamos, NM 87544

M. E. Gates, Manager Nevada Operations Office Department of Energy PO Box 14100

Las Vegas, NV 89114

R. J. Hart, Manager Oak Ridge Operations Office Department of Energy

PO Box E

Oak Ridge, TN 37830

J. J. Schreiber DOE Oak Ridge Operations Office PO BOX $X$

Oak Ridge, TN 37830

42 DOE Technical Information Center

W. M. Lamb, Manager

Rocky Flats Area Office

Department of Energy

Golden, CO 80401

ง. LaGrone, Acting Manager

San Francisco Operations Office

Department of Energy

1333 Broadway, Wells Fargo Bldg.

Dakland, CA 94612

N. Stetson, Manager

Savannah River Operations Office Department of Energy

PO Box A

Aiken, SC 29801

F. H. Anderson, General Manager

Allied Chemical Corporation

Idaho Chemical Programs--Operations Office

550 2nd St.

Idaho Falls, ID 83401

A. P. Roeh, Manager

Process Evaluation Branch

Allied Chemical Corporation

550 2nd St.

Idaho Falls, IO 83401
R. A. Brown

Allied Chemical Corporation

550 2nd St.

Idaho Falls, ID 83401

C. A. Hawley

Allied Chemical Corporation

550 2nd St.

Idaho Falls, ID 83401

D. A. Knecht

Allied Chemical Corporation 550 2nd St.

Idaho Falls, ID 83401

Allied Chemical Corporation

(File Copy)

550 2nd St.

Idaho Falls, ID 8340 I

J. A. Buckham

Ai Tied-General Nuclear Services PO Box 847

Barnwell, SC 29812

A. Williams

Allied-General Nuclear Services

PO Box 847

Barnwell, SC 29812

R. W. Kiehn, General Manager

EG\&G Idaho, Inc.

PO Box 1625

Idaho Falls, ID 83401

R. G. Sachs, Director

Argonne National Laboratory

9700 South Cass Avenue

Argonne, IL 60439

L. Burris

Argonne Natioral Laboratory

9700 South Cass Avenue

Argonne, IL 60439

J. L. Jardine

M. J. Steindler/L. E. Trevorrow

2 Argonne National Laboratory

9700 South Cass Avenue

Argonne, IL 60439

Eattelle Memorial Institute

505 King Avenue

Columbus, $\mathrm{OH} 43201$

J. M. Batch

Battel le Memorial Institute

505 king Avenue

Columbus, $\mathrm{OH} 43201$ 
No. of

\section{Copies}

G. H. Vineyard, Director Brookhaven National Laboratory Associated Universities, Inc. Upton, NY 11973

2 Brookhaven National Laboratory Reference Section Information Division Upton, Long Island, NY 11973

Combustion Division Combustion Engineering, Inc. Windsor, CT 06095

J. R. McClain, Director Monsanto Research Facility Mound Laboratory

PO Box 32

Miamisburg, OH 45342

C. J. Kershner

Monsanto Research Corporation Mound Laboratory

PO Box 32

Miamisburg, $\mathrm{OH} 45342$

H. M. Agnew, Director University of California LASL Los Alamos, NM 87544

T. K. Keenan

Group Leader, Waste Management University of California LASL

Los Alamos, NM 87544

Los Alamos Scientific Laboratory P0 Box 1663

Los Alamos, MM 87544

A. M. Sessler, Director Lawrence Berkeley Laboratory Berkeley, CA 94720

R. E. Batzel, Director Lawrence Livermore Laboratory PO Box 808

Livermore, CA 94550

H. Postma, Director Reference Section

Central Research Library Room 175-B, B1dg. $4500 \mathrm{~N}$

Oak Ridge National Laboratory PO Box $X$

Oak Ridge, TN 37830

D. B. Tranger

Associate Director

Oak Ridge National Laboratory

PO Box $X$

Oak Ridge, TN 37830
No. of

Copies

C. D. Zerby, Director

Office of Waste Isolation Union Carbide Corporation PO Box E

Oak Ridge, TN 37830

J. 0. Blomeke

Union Carbide Corporation (ORNL)

Chemical Technology Division

PO Box Y

Oak Ridge, TN 37830

2 D. E. Ferguson

Union Carbide Corporation (ORNL) Chemical Technology Division

PO Box Y

Oak Ridge, TN 37830

W. C. McClain

Union Carbide Corporation (ORNL)

Chemical Technology Division

PO Box Y

Oak Ridge, TN 37830

C. D. Zerby

Union Carbide Corporation

Nuclear Division

Office of Waste Isolation

PO Box Y

Oak Ridge, TN 37830

T. W. Laughl in

U.S. DOE Technical Information Center

PO Box 62

Oak Ridge, TN 37830

Morgan Sparks, President

Sandia Laboratories

PO Box 5800

Albuquerque, NM 87115

D. R. Anderson

Sandia Laboratories

Albuquerque, NM 87107

W. Weart

Division 1140

Sandia Laboratories

Albuquerque, NM 87107

H. D. Sivinski

Sandia Laboratories

Albuquerque, NM 87107

R. 0. Williams, General Manager Atomics International Division Rockwell International

Rocky Flats Plant

PO Box 464

Golden, CO 80401 
No. of

Copies

2 M. A. Thompson Rockwell International

Rocky Flats Division

Golden, C0 80401

T. B. Cook, Jr., Vice President

Sandia Laboratories

Livermore, CA 94550

C. H. Ice, Director Savannah River Laboratory

Aiken, SC 29801

M. D. Boersma

duPont Company, Aiken (DOE)

E.I. duPont DeNemours \& Co.

Savannah River Laboratory

Aiken, SC 29801

A. S. Jennings

duPont Company, Aiken (DOE)

E.I. duPont DeNemours \& Co.

Savannah River Laboratory

Aiken, SC 29801

Leon Meyers

duPont Company, Aiken (DOE)

E.I. duPont DeNemours \& Co.

Savannah River Laboratory

Aiken, SC 29801

P. H. Permar

duPont Company, Aiken (DOE)

E.I. duPont DeNemours \& Co.

Savannah River Laboratory

Aiken, SC 29801

R. A. Beall

U.S. Department of Interior

Bureau of Mines

Albany Research Center

$1450 \mathrm{~W}$. Queen Avenue

Albany, OR 97321

R. G. Post

College of Engineering

University of Arizona

Tucson, AZ 85721

S. E. Logan

University of New Mexico

Albuquerque, NM 87131

2 Central Research Library Document Reference Section Oak Ridge National Laboratory (DOE)

Oak Ridge, TN 37830 iro. of

Copies

L. Henning

Electric Power Research Institute

$3412 \mathrm{Hillview}$ Avenue

P0 Box 10412

Palo Alto, CA 94304

R. G. Barnes

General Electric Company

175 Curtner Avenue

(M/C 160)

san Jose, CA 95125

L. H. Brooks

Gulf Energy and Environmental Systems

PO Box 81608

San Diego, CA 92138

John Pomeroy, Technical Secretary

National Academy of Sciences

Committee of Radioactive Waste

Management

National Research Council

$2 i 01$ Constitution Avenue

Washington, DC 20418

J. P. Duckworth

Plant Manager

Nuclear Fuel Services, Inc.

PO Box 124

West Valley, NY 14171

J. G. Cline, General Manager

NYS Atomic Space and Development Authority

230 Park Avenue, Rm. 2425

New York, NY 10017

ONSITE

5 DOE Richland Operations Office
0. 3. Elgert
A. Fremling
R. B. Goranson
H. E. Ransom
M. J. Zamorski

9 Rockwell Hanford Operations

H. Babid

D. J. Cockeram

R. A. Deju

R. J. Gimara

E. J. Kosiancic

C. M. Manry

J. H. Roecker

D. D. Wodrich

File Copy 
Distr-5

No. of

Copies

Exxon

Richland, WA 99352

S. J. Beard

Joint Center for Graduate Study

J. Cooper

2 United Nuclear industries, inc.

T. E. Dabrowski

A. E. Engler

3 Westinghouse Hanford Company

A. G. Blasewitz

E. A. Evans

A. Squire
No. of

Copies

49 Pacific Northwest Laboratory

T. W. Ambrose

J. W. Bartlett

L. L. Burger

H. C. Burkholder

J. S. Burlison

N. E. Carter

D. B. Cearlock

T. D. Chikalla

R. L. Dillon

J. W. Finnigan

J. J. Fuquay

K. M. Harmon (20)

A. J. Haverfield

R. E. Heineman

E. R. Irish

J. H. Jarrett

R. P. Marshall

J. L. McElroy

R. E. Nightingale

D. E. Olesen

A. M. Platt

C. M. Unruh

H. H. Van Tuy]

L. D. Williams

Technical Information (5)

Technical Publications

Sharon Cozad 
